\title{
Evolution of Geochemical and Mineralogical Parameters during In Situ Remediation of a Marine Shore Tailings Deposit by the Implementation of a Wetland Cover
}

\author{
Nouhou Diaby ${ }^{1,2}$ and Bernhard Dold ${ }^{1,3, *}$ \\ 1 Institut de Minéralogie et Géochimie, Université de Lausanne, CH-1015 Lausanne, Switzerland \\ 2 Present Address: Laboratoire de Traitement des Eaux usées, Institut Fondamental d'Afrique Noire \\ (IFAN), Université Cheikh Anta Diop, BP 206 Dakar, Senegal; E-Mail: nouhou.diaby@ucad.edu.sn \\ 3 Present Address: SUMIRCO (Sustainable Mining Research \& Consult EIRL), Casilla 28, \\ San Pedro de la Paz 4130000, Chile
}

* Author to whom correspondence should be addressed; E-Mail: bernhard.dold@gmail.com; Tel.: +56-9-7762-6394.

Received: 27 February 2014; in revised form: 23 June 2014 / Accepted: 24 June 2014 /

Published: 8 July 2014

\begin{abstract}
We present data of the time-evolution of a remediation approach on a marine shore tailings deposit by the implementation of an artificial wetland. Two remediation cells were constructed: one in the northern area at sea-level and one in the central delta area (above sea-level) of the tailings. At the beginning, the "sea-level" remediation cell had a low $\mathrm{pH}$ (3.1), with high concentrations of dissolved metals and sulfate and chloride ions and showed sandy grain size. After wetland implementation, the "sea-level" remediation cell was rapidly water-saturated, the acidity was consumed, and after four months the efficiency of metal removal from solution was up to $79.5 \%-99.4 \%$ for $\mathrm{Fe}, 94.6 \%-99.9 \%$ for $\mathrm{Mn}$, and $96.1 \%-99.6 \%$ for $\mathrm{Zn}$. $\mathrm{Al}$ and $\mathrm{Cu}$ concentrations decreased below detection limit. The "above sea-level" remediation cell was characterized by the same $\mathrm{pH}$ (3.1) and finer grain size (clayey-silty), and with some lower element concentrations than in the "sea-level" cell. Even after one year of flooding, the "above sea-level" cell was not completely flooded, showing on-going sulfide oxidation in between the wetland cover and the groundwater level; the $\mathrm{pH}$ increased only to 4.4 and metal concentrations decreased only by $96 \%$ for $\mathrm{Fe}, 88 \%$ for $\mathrm{Al}, 51 \%$ for $\mathrm{Cu}, 97 \%$ for $\mathrm{Mn}$, and $95 \%$ for $\mathrm{Zn}$. During a dry period, the water level dropped in the "sea-level" cell, resulting in a seawater ingression, which triggered the desorption of As into solution. These data show that the applied
\end{abstract}


remediation approach for this tailings deposit is successful, if the system is maintained water-saturated. Metal removal from solution was possible in both systems: first, as a result of sorption on $\mathrm{Fe}$ (III) hydroxide/and/or clay minerals and/or co-precipitation processes after rise of $\mathrm{pH}$; and then, with more reducing conditions, due to metal sulfides precipitation.

Keywords: acid mine drainage; bioremediation; sulfate-reducing bacteria; metal removal

\section{Introduction}

Sulfide oxidation in mine tailings is a major source of acid mine drainage (AMD) production [1,2]. Several treatment approaches (active and passive) have been proposed for AMD mitigation. Active treatment usually consists of the addition of lime or a chemical neutralizing agent in order to increase the $\mathrm{pH}$ and to precipitate metals on hydroxides and carbonates [3] or as sulfides [4] and/or adsorb them onto a sorbent. The neutralizing agents, unless they are available in situ, have to be quarried and transported over long distances, which can make this approach capital intensive. Contrariwise, the lower operating costs of passive treatment such as wetland construction make them attractive for the mining industry. Constructed wetlands have been successfully applied to several mining environments to remove contaminants from water, especially from metal-rich effluent [3,5]. The mechanisms of metal removal from AMD using wetland are mainly the sorption and co-precipitation processes with iron oxides and hydroxides as well as the precipitation of metal sulfides.

The in situ remediation at the source of AMD formation may help to mitigate AMD, but also to prevent its future formation by avoiding sulfide oxidation. Wetland cover directly on the tailings is a strategy, that was applied and in some cases, demonstrated high efficiency [6-10]. This method is based on limitation of the oxidation processes, the sorption of metals on mineral surface and metal removal by sulfide precipitation.

In addition, geochemical processes involved in tailings wetlands are mediated or accelerated by microbial activities. Wetlands promote optimal conditions for sulfate reduction by sulfate-reducing bacteria (SRB) producing hydrogen sulfide which will react and precipitate with metals. On the other hand, the geochemical reactions mediated by SRB generate alkalinity, participating to acidity neutralization. The role of this microbial group in metal removal processes has been described in various studies [11-14].

The overall study of the remediation of the Bahia de Ite tailings impoundment, Peru is published elsewhere [10]. We concentrate in the present study on the evolution of the geochemical and mineralogical changes during a real-scale in situ remediation experiment at the site in order to highlight the controlling parameters for the effective function of the remediation process. The aim of the study was (i) to investigate the effect on element cycling during the flooding of the oxidizing porphyry copper tailings in a marine setting with two different waters (river water and wetland water); (ii) to highlight the evolution of mineralogical and (bio)geochemical changes over time; and (iii) to evaluate the long-term effectiveness of the bioremediation process. 


\section{Experimental Section}

\subsection{Preparation of the Remediation Cell}

Two remediation cells of $30 \mathrm{~m} \times 30 \mathrm{~m}$ were constructed in September and October 2005 in the northern section (Northern Cell, NC) close to the shoreline at sea-level and in the delta area (Delta Cell, DC), about two meters above sea-level, of the tailings deposit (Figure 1). The surrounding dikes (about $70 \mathrm{~cm}$ high) were constructed manually using tailings material, and a piezometers nest (drive point piezometers) was installed in the center of each cell (Figure 1C). Before the flooding of the cell, the groundwater level was about $0.5 \mathrm{~m}$ depth in the $\mathrm{NC}$ and $1.5 \mathrm{~m}$ in the DC.

Figure 1. Overview of the Bahía de Ite (Ite bay) marine shore tailings deposit, Peru with the location of the remediation cells and the sampling points of the overall study of the system reported by Dold et al. [10]. (A) = Map of the tailings deposit; (B) = Profile of the northern section of the tailings deposit (the scale is exaggerated for better visibility); (C) $=$ Change of the remediation cell located in the delta area from oxidizing tailings to a wetland cover.

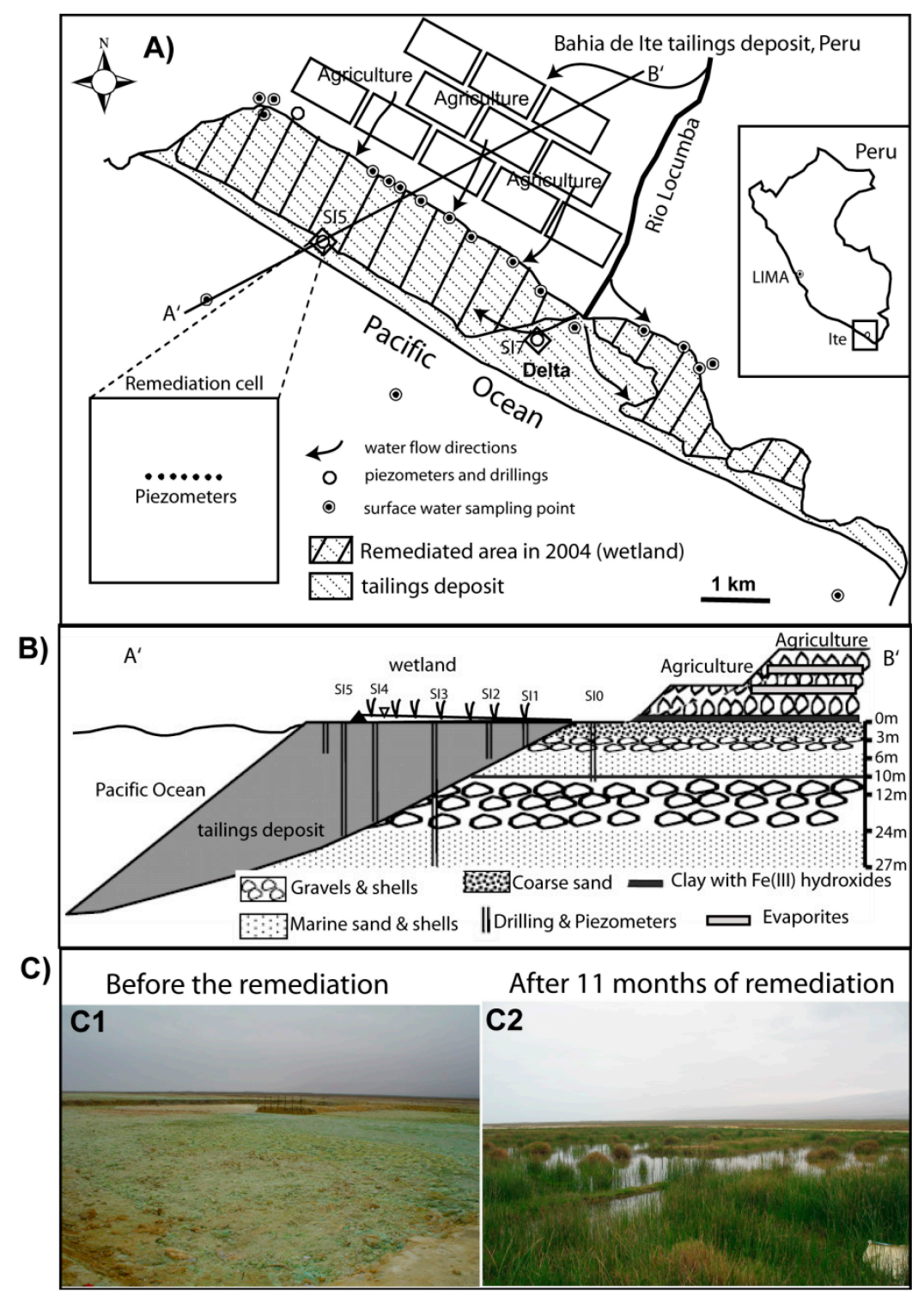


The NC cell, with mainly sandy grain size, was flooded using water from the wetland (Figure 1 and Table 1) covering the already remediated tailings areas close by. Due to the high water saturation in the wetland area, the NC was saturated after five days of flooding. The monitoring of this remediation cell was performed from October 2005 to July 2006.

The DC, which showed a more heterogenic stratigraphy with mainly clayey and fine-sandy horizons (Table 1), was flooded using water channeled from the Locumba River (Rio Locumba). This cell could not be completely saturated during all the course of the experiment, as the delta area is topographically elevated in relation to the rest of the tailings deposit (up to $2 \mathrm{~m}$ higher).

The monitoring of the remediation cells was performed from September 2005 to November 2007. Both cells were planted with local vegetation that developed in previously remediated sections of the tailings. Figure $1 \mathrm{C}$ shows the change in the delta remediation cell at the beginning and after 11 months of remediation.

Table 1. Characterization of the remediation cell at the start of the experiment and the geochemical composition of the water used for flooding. DOC $=$ Dissolved Organic Carbon.

\begin{tabular}{|c|c|c|c|}
\hline \multicolumn{2}{|l|}{ Characteristics } & Northern Cell (NC) & Delta Cell (DC) \\
\hline \multirow{4}{*}{\multicolumn{2}{|c|}{$\begin{array}{l}\text { Grain size } \\
\text { Groundwater level } \\
\text { Location } \\
\text { Altitude }\end{array}$}} & Sandy & Clayey-silty \\
\hline & & Groundwater level at $1 \mathrm{~m}$ & Groundwater level at $1.5 \mathrm{~m}$ \\
\hline & & Close to shore line & Close to river inflow \\
\hline & & Sea water level & $2 \mathrm{~m}$ above sea water level \\
\hline \multirow{20}{*}{$\begin{array}{l}\text { Characteristics } \\
\text { of water used } \\
\text { for remediation }\end{array}$} & Origin & From the old wetland & From Locumba river \\
\hline & $\mathrm{pH}$ & 7.6 & 7.3 \\
\hline & $\mathrm{Eh}$ & 341 & 420 \\
\hline & Alkalinity $\left(\mathrm{mg} / \mathrm{L} \mathrm{CaCO}_{3}\right)$ & 241 & 133 \\
\hline & $\mathrm{DOC}(\mathrm{mg} / \mathrm{L})$ & 8.36 & 2.6 \\
\hline & Fe total $(\mathrm{mg} / \mathrm{L})$ & 0.08 & $<0.005$ \\
\hline & FeII (mg/L) & $<0.1$ & $<0.1$ \\
\hline & $\mathrm{Al}(\mathrm{mg} / \mathrm{L})$ & 0.05 & 0.1 \\
\hline & $\mathrm{Cu}(\mathrm{mg} / \mathrm{L})$ & 0.12 & 0.03 \\
\hline & $\mathrm{Ni}(\mathrm{mg} / \mathrm{L})$ & $<0.02$ & $<0.02$ \\
\hline & $\mathrm{Mn}(\mathrm{mg} / \mathrm{L})$ & 0.39 & $<0.01$ \\
\hline & $\operatorname{Mg}(\mathrm{mg} / \mathrm{L})$ & 100 & 37.4 \\
\hline & $\mathrm{K}(\mathrm{mg} / \mathrm{L})$ & 56 & 29.1 \\
\hline & $\mathrm{Zn}(\mathrm{mg} / \mathrm{L})$ & $<0.04$ & $<0.04$ \\
\hline & As (mg/L) & 0.07 & 0.27 \\
\hline & Mo (mg/L) & 0.06 & $<0.04$ \\
\hline & $\mathrm{Cl}(\mathrm{mg} / \mathrm{L})$ & 2080 & 433 \\
\hline & $\mathrm{Ca}(\mathrm{mg} / \mathrm{L})$ & 274 & 141 \\
\hline & $\mathrm{Na}(\mathrm{mg} / \mathrm{L})$ & 1555 & 300 \\
\hline & $\mathrm{SO}_{4}(\mathrm{mg} / \mathrm{L})$ & 1636 & 429 \\
\hline
\end{tabular}

\subsection{Sampling}

Solid (in total 246 samples) and water (in total 376 samples) samples were taken daily during the first week from the piezometer nest and the surface waters; then weekly until the 7 th week, and after 
that, monthly. Samples were taken for geochemical, mineralogical, and microbiological parameters (the microbiological study will be published elsewhere). Solid samples were taken using a percussion soil sampler. Paste-pH after the method described by Mine Environment Neutral Drainage (MEND) Program [15] was measured and the tailings were described by color, grain size, and texture. The water samples in the saturated zone (Solinst ${ }^{\circledR}$ Drive-point piezometers, Georgetown, ON, Canada) were taken with a peristaltic pump. In the unsaturated vadose zone, water samples were taken using squeezing technique modified after Coggans et al. [16] before the remediation process to obtain the geochemical starting conditions. After remediation started, the piezometers and the surface water in the remediation cell were sampled. All water samples were filtered $(0.2 \mu \mathrm{m}$; regenerated cellulose $)$ and stored at $+4{ }^{\circ} \mathrm{C}$ in darkness prior to analysis. Samples for cations analyses were acidified to $\mathrm{pH}<2$ with Suprapure ${ }^{\circledR}$ Merck $\mathrm{HNO}_{3}$. Specific geochemical variables ( $\mathrm{pH}, \mathrm{Eh}, \mathrm{Fe}^{2+}$, and alkalinity) were measured immediately during sampling in a flow-cell fed by a peristaltic pump. The performance of the Eh electrodes was controlled by Light and Zobell's solutions and the values were corrected with respect to the standard hydrogen electrode (SHE). Alkalinity was measured with a Hach ${ }^{\circledR}$ digital titrator (Loveland, CO, USA) and $\mathrm{Fe}^{2+}$ with a Merck Reflectoquant ${ }^{\circledR}$ reflectometer (Darmstadt, Germany). The complete data set is given in the supplementary information.

\subsection{Mineralogical Analysis}

Polished sections and polished thin sections were prepared from selected bulk samples. Selected samples were analyzed for mineralogy by X-ray diffraction (XRD), using a Philips 3020 diffractometer (Amsterdam, The Netherlands) with $\mathrm{CuK} \alpha(k=1.54056 \AA)$ and a monochromator. Scan settings were $3^{\circ}-70^{\circ} 2 \theta, 0.02^{\circ}$ step size, 2 -s count time per step.

\subsection{Grain Size Analysis}

The grain size analysis was performed using a Beckman Coulter LS 13320 laser-particle analyzer (Brea, CA, USA) with universal liquid module (ULM).

\subsection{Aquatic Geochemistry}

Water samples (376 samples) were analyzed for 20 elements (Ag, Al, B, Ba, Ca, Cd, Co, Cr, Cu, $\mathrm{Fe}, \mathrm{K}, \mathrm{Mg}, \mathrm{Mn}, \mathrm{Mo}, \mathrm{Na}, \mathrm{Ni}, \mathrm{Pb}, \mathrm{Sb}, \mathrm{SiO}_{2}, \mathrm{Zn}$ ) by inductively coupled plasma atomic emission spectroscopy (ICP-AES) (Perkin Elmer HP 3000 DV, Waltham, MA, USA), and As and Se was measured by atomic absorption spectroscopy (AAS) with hydride system (Perkin Elmer FIAS-400). $\mathrm{SO}_{4}$ and $\mathrm{Cl}$ were measured by ion chromatography (IC; Dionex DX 120, Sunnyvale, CA, USA) and dissolved organic carbon (DOC) by High Temperature TOC/TNb Analyzer LiquiTOC ${ }^{\circledR}$ (Elementar, Hanau, Germany).

\subsection{Sequential Extractions}

The solid geochemistry was analyzed by a seven-step sequential extraction approach [17]. The analysis was done on selected samples from the oxidation zone of the two remediation cells $(0-1 \mathrm{~m})$. In the first step, a $1.0 \mathrm{~g}$ sample was mixed into $50 \mathrm{~mL}$ deionized $\mathrm{H}_{2} \mathrm{O}$ and shaken for $1 \mathrm{~h}$ to dissolve 
the water-soluble secondary and tertiary sulfate (e.g., bonattite, chalcanthite, gypsum, pickeringite, magnesioauberite). The second step used $\mathrm{NH}_{4}$-acetate at $\mathrm{pH} 4.5$ shaken for $2 \mathrm{~h}$ to detach the exchangeable ions and carbonates (calcite, vermiculite-type-mixed-layer). The third one used $0.2 \mathrm{M}$ $\mathrm{NH}_{4}$-oxalate $\mathrm{pH} 3.0$ (shaken for $1 \mathrm{~h}$ in darkness) to dissolves the Fe oxyhydroxides (schwertmannite, 2-line ferrihydrite, secondary jarosite, $\mathrm{MnO}_{2}$ ). The fourth step used $0.2 \mathrm{M} \mathrm{NH}_{4}$-oxalate $\mathrm{pH} 3.0$ (heated in water bath $80^{\circ} \mathrm{C}$ for $2 \mathrm{~h}$ ) to dissolve the hydroxides and oxides (goethite, jarosite, natrojarosite, and hematite, magnetite, higher ordered ferrihydrite's (e.g., 6-line ferrihydrite). In the fifth step, 35\% $\mathrm{H}_{2} \mathrm{O}_{2}$ (heat in water bath for $1 \mathrm{~h}$ ) was used to leach the elements associated to organics, covellite, chalcocite-digenite. The sixth step combined $\mathrm{KClO}_{3}$ and $\mathrm{HCl}$, followed by $4 \mathrm{M} \mathrm{HNO}_{3}$ boiling to dissolve the sulfides (pyrite, chalcopyrite, bornite, sphalerite, galena, molybdenite, tetrahedrite, cinnabar, orpiment, and stibnite). Finally, the seventh step used $\mathrm{HNO}_{3}, \mathrm{HF}, \mathrm{HClO}_{4}, \mathrm{HCl}$ digestion to separate the residual elements attached on silicates. After extraction, multi-element (31 elements) analyses were performed in the leachates by inductively coupled plasma optical emission spectrometer (ICP-OES) at the SGS Laboratories of Toronto, Canada. The complete data set is given in the supplementary information.

\section{Results and Discussion}

\subsection{Stratigraphy and Mineralogy before Remediation}

The mineralogical and geochemical characterization from oxidizing tailings at the Bahia de Ite was discussed in detail by Dold et al. [10]. We present here the mineralogy and geochemistry of the two remediation test cells just before the remediation experiment started for the reader's convenience.

The stratigraphy of both remediation cells was characterized by a cover of efflorescent salts on the surface containing mainly water-soluble sulfates and minor chlorides: tamarugite $\left(\mathrm{NaAl}\left(\mathrm{SO}_{4}\right)_{2} \cdot 6 \mathrm{H}_{2} \mathrm{O}\right.$, hexahydrite $\left(\mathrm{MgSO}_{4} \cdot 6 \mathrm{H}_{2} \mathrm{O}\right)$, pentahydrite $\mathrm{Mg}\left(\mathrm{SO}_{4}\right)\left(\mathrm{H}_{2} \mathrm{O}\right)_{5}$, aubertite $\mathrm{AlCuCl}\left(\mathrm{SO}_{4}\right)_{2}\left(\mathrm{H}_{2} \mathrm{O}\right)_{14}$, melanterite $\left(\mathrm{FeSO}_{4}\left(\mathrm{H}_{2} \mathrm{O}\right)_{7}\right.$, siderotil $(\mathrm{Fe}, \mathrm{Cu}) \mathrm{SO}_{4} \cdot 5 \mathrm{H}_{2} \mathrm{O}$, bloedite $\mathrm{Na}_{2} \mathrm{Mg}\left(\mathrm{SO}_{4}\right)_{2} \cdot 4 \mathrm{H}_{2} \mathrm{O}$, thenardite $\mathrm{Na}_{2} \mathrm{SO}_{4}$, dansite $\mathrm{Na}_{21} \mathrm{Mg}\left(\mathrm{SO}_{4}\right) 10 \mathrm{C}_{13}$; halite $(\mathrm{NaCl})$, eriochalcite $\mathrm{CuCl}_{2} \cdot 2 \mathrm{H}_{2} \mathrm{O}$, atacamite $\left(\mathrm{Cu}_{2} \mathrm{Cl}(\mathrm{OH})_{3}\right)$. This enrichment of the mobile elements from the oxidation zone towards the surface was controlled by the high evaporation in the Atacama Desert, which induced a strong capillary transport to the tailings surface, a process commonly observed in arid climates [2,18]. In the northern cell, where the grain size was sandy, the efflorescent salts precipitated mainly in between the sands, whereas in the delta area, a crust of efflorescent salts up to $20 \mathrm{~cm}$ thick evolved above this more silty-clayey tailings surface.

The mineralogy of the underlying oxidation zone was dominated by quartz, muscovite, biotite, feldspar (albite-sanidine-anorthoclase), anhydrite, gypsum, a vermiculite-type mixed layer mineral resulting from the alteration of biotite [2] and pyrite. This low-paste $\mathrm{pH}$ oxidation zone ( $\mathrm{pH} 2-4)$ showed straw-yellowish color (jarosite), with orange-ochre-brown Fe(III) hydroxides (goethite and schwertmannite), which were mainly related to dehydration cracks and grain size limits, where the $\mathrm{Fe}(\mathrm{III})$-rich solutions percolated [10]. Below the oxidation zone, the underlying neutral primary zone was characterized by the primary mineral assemblage from the ore (quartz, muscovite, biotite, feldspar (albite-sanidine-anorthoclase), anhydrite, gypsum), with about 4\% pyrite and traces of chalcopyrite, molybdenite, chalcocite-covellite. 
At the northern remediation cell, the tailings consisted of sandy sediment due to grain size separation by the wave action. The primary zone had an orange-reddish color along the whole depth. This was interpreted as a consequence of the Fe(II) resulting from the tailings oxidation zone, which was pushed during the remediation towards the shoreline. The contact of the Fe(II) with more oxidizing water results in oxidation into Fe(III) hydroxide, which in turn coats the sediments. Additionally, reductive dissolution of a Fe(III) oxide-rich horizon at $10 \mathrm{~m}$ depth is an additional source for the iron coating [10].

In contrast, the delta area was characterized by a mixed stratigraphy of silty, clayey, and very fine-sandy layers. This cell had a clear separation between oxidation and primary zone. From 0 to $1 \mathrm{~m}$ were oxidizing tailings (yellow-brownish-orange). Just below and up to $1.7 \mathrm{~m}$ depth, a first grey primary zone was present, followed by the former oxidation zone up to $4.4 \mathrm{~m}$ depth and then underlain by a second primary zone. A $10 \mathrm{~cm}$ thick pyrite horizon was present at $3.2 \mathrm{~m}$ depth. This stratigraphy is explained by an ultimate fresh tailings deposition done above the old oxidation zone in 1992, due to a break of a dike in the channel transporting the tailings in the bay.

\subsection{Geochemical Evolution of the Wetland}

\subsubsection{The Sandy Northern Remediation Cell (NC)}

Starting Conditions before Remediation

At the northern remediation cell, the starting geochemical conditions in the pore water were as follows: pore water in the oxidation zone showed $\mathrm{pH} 3.1$ and a redox potential of up to $358 \mathrm{mV}$ (Table 2) with high concentration of heavy metal in solution of up to $12.9 \mathrm{mg} / \mathrm{L} \mathrm{Zn}, 80.1 \mathrm{mg} / \mathrm{L} \mathrm{Mn}, 104 \mathrm{mg} / \mathrm{L} \mathrm{Al}$, $176 \mathrm{mg} / \mathrm{L} \mathrm{Fe}, 308 \mathrm{mg} / \mathrm{L} \mathrm{Mg}, 329 \mathrm{mg} / \mathrm{L} \mathrm{Cu}$. Below the oxidation zone high concentrations of Fe(II) were detected (up to $242 \mathrm{mg} / \mathrm{L} \mathrm{Fe}$ ), feature typically observed in oxidizing sulfidic tailings, due to microbial iron reduction processes [18]. Arsenic concentrations averaged $0.16 \mathrm{mg} / \mathrm{L}$, which was lower than the natural background of the inflowing water from the Locumba River (average $0.5 \mathrm{mg} / \mathrm{L}$ ) [10]. This may be due to the adsorption of arsenate onto iron hydroxides at low $\mathrm{pH}$ conditions. Below the oxidation zone, $\mathrm{pH}$ increased up to 6.5 at $10 \mathrm{~m}$ depth and $\mathrm{Eh}$ decreased to $256 \mathrm{mV}$. Due to these geochemical conditions, heavy metal concentrations in the pore water were low in the primary zone. Chloride, sodium and sulfate showed concentration of 2125 and 1748, and $4167 \mathrm{mg} / \mathrm{L}$, respectively (Table 2). Two peak concentrations of sulfate in the stratigraphy were observed. In the upper part, the oxidation zone showed concentrations of up to $4167 \mathrm{mg} / \mathrm{L}$ due to sulfide oxidation (supported by isotopic data) [10]. Below, the sulfate concentrations stabilize around $2100 \mathrm{mg} / \mathrm{L}$ due to gypsum solubility control. The increase towards $2861 \mathrm{mg} / \mathrm{L} \mathrm{SO}_{4}{ }^{2-}$ at $10 \mathrm{~m}$ depth was interpreted as the only sign of seawater influence detected in the deposit, which was also supported by stable isotopic data. 
Table 2. Geochemistry of ground water in the Northern Cell (NC) before the start of the remediation experiment.

\begin{tabular}{|c|c|c|c|c|c|c|c|c|c|c|}
\hline Samples & $\begin{array}{c}\text { Depth } \\
\text { (m) }\end{array}$ & pH & $\begin{array}{c}\text { EC } \\
(\mathrm{ms} / \mathrm{cm})\end{array}$ & $\begin{array}{c}\text { Eh } \\
(\mathbf{m V})\end{array}$ & $\begin{array}{c}\text { Alkalinity } \\
\left(\mathrm{mg} / \mathrm{L} \mathrm{CaCO}_{3}\right)\end{array}$ & $\begin{array}{c}\text { Al } \\
(\mathrm{mg} / \mathrm{L}) \\
\end{array}$ & $\begin{array}{c}\mathrm{As} \\
(\mathrm{mg} / \mathrm{L}) \\
\end{array}$ & $\begin{array}{c}\mathrm{Ca} \\
(\mathrm{mg} / \mathrm{L}) \\
\end{array}$ & $\begin{array}{c}\mathrm{Cl} \\
(\mathrm{mg} / \mathrm{L}) \\
\end{array}$ & $\begin{array}{c}\text { Co } \\
(\mathrm{mg} / \mathrm{L}) \\
\end{array}$ \\
\hline SI5P1 & 1 & 3.1 & 7.63 & 358 & $<1.5$ & 104 & 0.02 & 332 & 2125 & 0.89 \\
\hline SI5P2 & 2 & 4.0 & 7.20 & 342 & $<1.5$ & 97.2 & 0.15 & 400 & 2085 & 0.74 \\
\hline SI5P3 & 3 & 4.4 & 8.00 & 253 & $<1.5$ & 51.1 & 0.12 & 591 & 2245 & 0.53 \\
\hline SI5P4 & 4 & 5.4 & 6.15 & 274 & 30.2 & 0.25 & $<0.02$ & 343 & 1830 & 0.04 \\
\hline SI5P6 & 6 & 6.5 & 6.25 & 286 & 105 & $<0.05$ & $<0.02$ & 223 & 1875 & $<0.02$ \\
\hline SI5P8 & 8 & 6.4 & 7.55 & 222 & 116.5 & $<0.05$ & $<0.02$ & 243 & 2655 & $<0.02$ \\
\hline SI5P10 & 10 & 6.5 & 10.6 & 256 & 112 & $<0.05$ & 0.05 & 307 & 3860 & 0.06 \\
\hline Samples & $\begin{array}{c}\text { Depth } \\
\text { (m) }\end{array}$ & $\begin{array}{c}\mathrm{Cu} \\
(\mathrm{mg} / \mathrm{L})\end{array}$ & $\begin{array}{c}\mathrm{Fe} \\
(\mathrm{mg} / \mathrm{L})\end{array}$ & $\begin{array}{c}\mathrm{K} \\
(\mathrm{mg} / \mathrm{L})\end{array}$ & $\begin{array}{c}\mathrm{Mg} \\
(\mathrm{mg} / \mathrm{L})\end{array}$ & $\begin{array}{c}\text { Mn } \\
(\mathrm{mg} / \mathrm{L})\end{array}$ & $\begin{array}{c}\text { Mo } \\
(\mathrm{mg} / \mathrm{L})\end{array}$ & $\begin{array}{c}\mathrm{Na} \\
(\mathrm{mg} / \mathrm{L})\end{array}$ & $\begin{array}{c}\mathrm{SO}_{4} \\
(\mathrm{mg} / \mathrm{L})\end{array}$ & $\begin{array}{c}\mathrm{Zn} \\
(\mathrm{mg} / \mathrm{L})\end{array}$ \\
\hline SI5P1 & 1 & 329 & 176 & 21.0 & 308 & 80.1 & 0.05 & 1748 & 4167 & 12.9 \\
\hline SI5P2 & 2 & 229 & 154 & 57.5 & 267 & 64.2 & 0.35 & 1674 & 3807 & 10.4 \\
\hline SI5P3 & 3 & 140 & 242 & 71.2 & 358 & 23.7 & 0.32 & 1814 & 4581 & 5.98 \\
\hline SI5P4 & 4 & 3.57 & 10.6 & 53.3 & 197 & 1.23 & 0.07 & 1449 & 2124 & 0.22 \\
\hline SI5P6 & 6 & 0.17 & 1.13 & 55.9 & 137 & 0.37 & $<0.04$ & 1774 & 2162 & 0.05 \\
\hline SI5P8 & 8 & 0.03 & 5.7 & 61.0 & 129 & 0.88 & $<0.04$ & 2245 & 2174 & 0.05 \\
\hline SI5P10 & 10 & 0.10 & 54.1 & 75.6 & 157 & 5.57 & $<0.04$ & 3167 & 2861 & 0.75 \\
\hline
\end{tabular}

Evolution of the Aquatic Geochemistry in the Surface Waters of the Northern Remediation Cell (NC)

The water used for this remediation cell was taken directly from the wetland and had $\mathrm{pH}$ of 7.6, Eh of $341 \mathrm{mV}$ and concentrations of heavy metals were close to or below detection limit (Figure 2). The other geochemical parameters showed the following concentrations: $100 \mathrm{mg} / \mathrm{L} \mathrm{Mg}, 0.07 \mathrm{mg} / \mathrm{L} \mathrm{As}$, $2080 \mathrm{mg} / \mathrm{L} \mathrm{Cl}, 1555 \mathrm{mg} / \mathrm{L} \mathrm{Na}, 1636 \mathrm{mg} / \mathrm{L} \mathrm{SO}_{4}{ }^{2-}$, and $8.36 \mathrm{mg} / \mathrm{L} \mathrm{DOC}$. Thus, the water from the wetland has about three-fold higher concentrations in DOC, nearly double in alkalinitiy and is more reducing than the Locumba river water used for the DC (Table 1), which might be an additional factor in accelerating the change to a neutral and reducing environment. After the flooding of the oxidizing tailings, the $\mathrm{pH}$ remained between 7 and 8. The Eh increased from 341 up to $416 \mathrm{mV}$ and then was decreasing over time reaching $205 \mathrm{mV}$ at the end of the experiment. Alkalinity decreased from 250 to $150 \mathrm{mg} / \mathrm{L}$ at the beginning of the experiment and stabilized around $180 \mathrm{mg} / \mathrm{L}$. $\mathrm{Zn}$ and $\mathrm{Al}$ remained below detection limit, whereas $\mathrm{Fe}, \mathrm{Mn}$ and $\mathrm{Cu}$ were fluctuating at low concentrations between 0 and $0.3 \mathrm{mg} / \mathrm{L}$ (Figure 2). The efflorescent salts, which were exposed at the surface of the tailings cell, were dissolved and leached downward during the five days before the water saturation of the cell and the installation of the water cover. Once the remediation cell was saturated, the height of the water cover inside the cell was about $50 \mathrm{~cm}$.

Seventy-five days after the remediation started, arsenic, chloride, sodium, and sulfate showed an increase in concentration up to $0.9 \mathrm{mg} / \mathrm{L}, 3600 \mathrm{mg} / \mathrm{L}, 3200 \mathrm{mg} / \mathrm{L}$ and $3000 \mathrm{mg} / \mathrm{L}$, respectively. These high concentrations were maintained until day 150, before dropping down again (Figure 2 and supplementary information). This increase in concentrations correlates with the dry season, where low water supply results in an increase of these elements in solution due to strong evaporation in the surface waters of the cell. Additionally, due to the lower water level in the wetland during the dry 
season, the hydraulic gradient decreased, so that the freshwater-seawater interface migrated towards the shore, resulting in an increase of chloride, sodium, and sulfate in the whole profile (see Figure 3G,H). This was confirmed by isotopic analyses, which showed value of $\delta^{34} \mathrm{~S}$ and $\delta^{18} \mathrm{O}$ closer to seawater values during the period [10]. The increasing concentrations of As in the cell water seemed to be linked to the increasing concentrations of other competing anions like $\mathrm{Cl}^{-}$and $\mathrm{SO}_{4}{ }^{2-}$ for the sorption sites in the oxidation zone, resulting in the release of As into solution. This will be discussed in more detail in the following sections.

Figure 2. Evolution of hydrogeochemistry in the water cover of the Northern Cell during the remediation process. In the time-scale axes, the arrow (day 0) corresponds to the water sample taken at the start of the experiment before flooding.
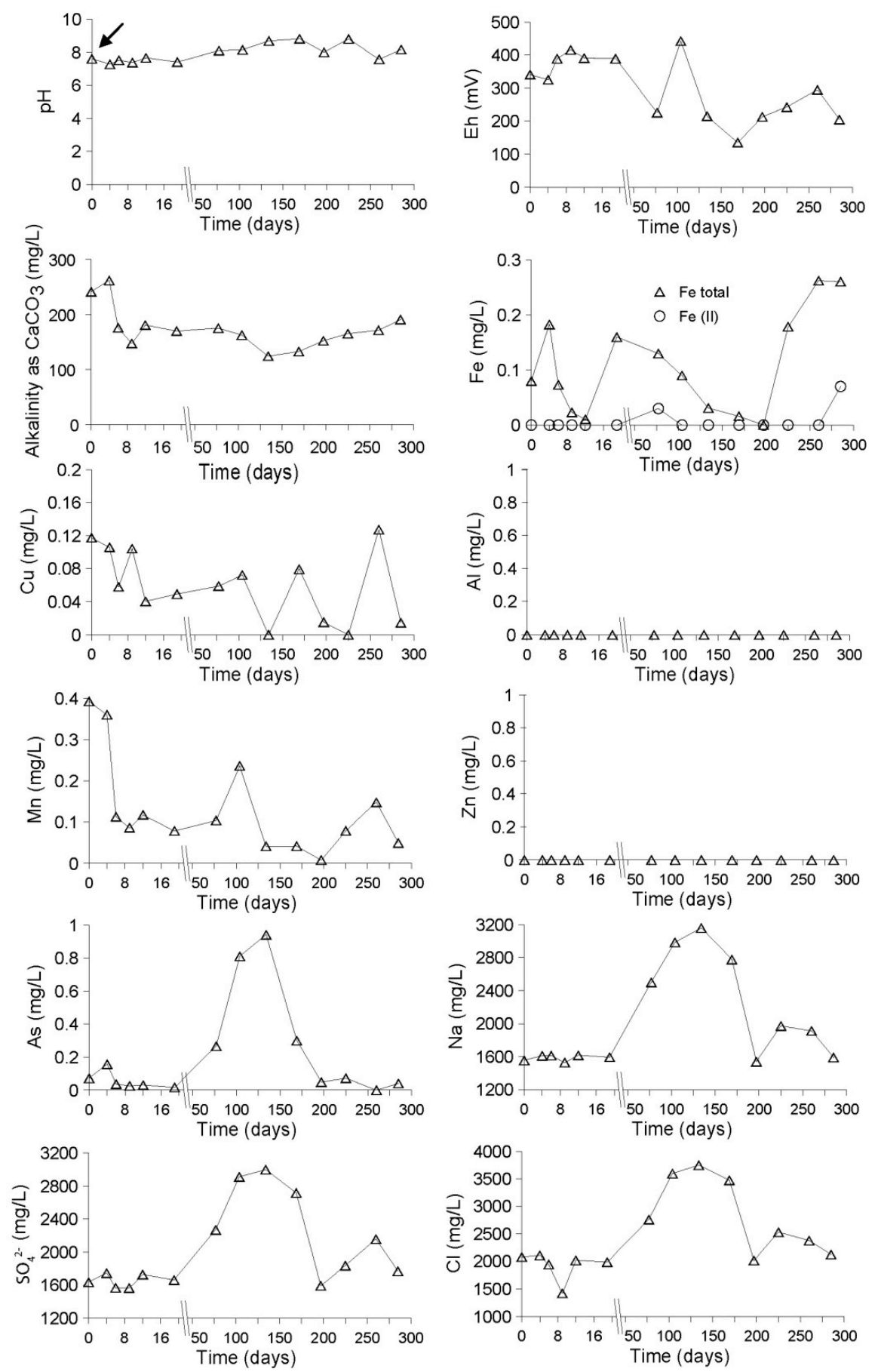
Figure 3. Evolution of hydrogeochemistry in the piezometer nest of the Northern Cell during the remediation process.

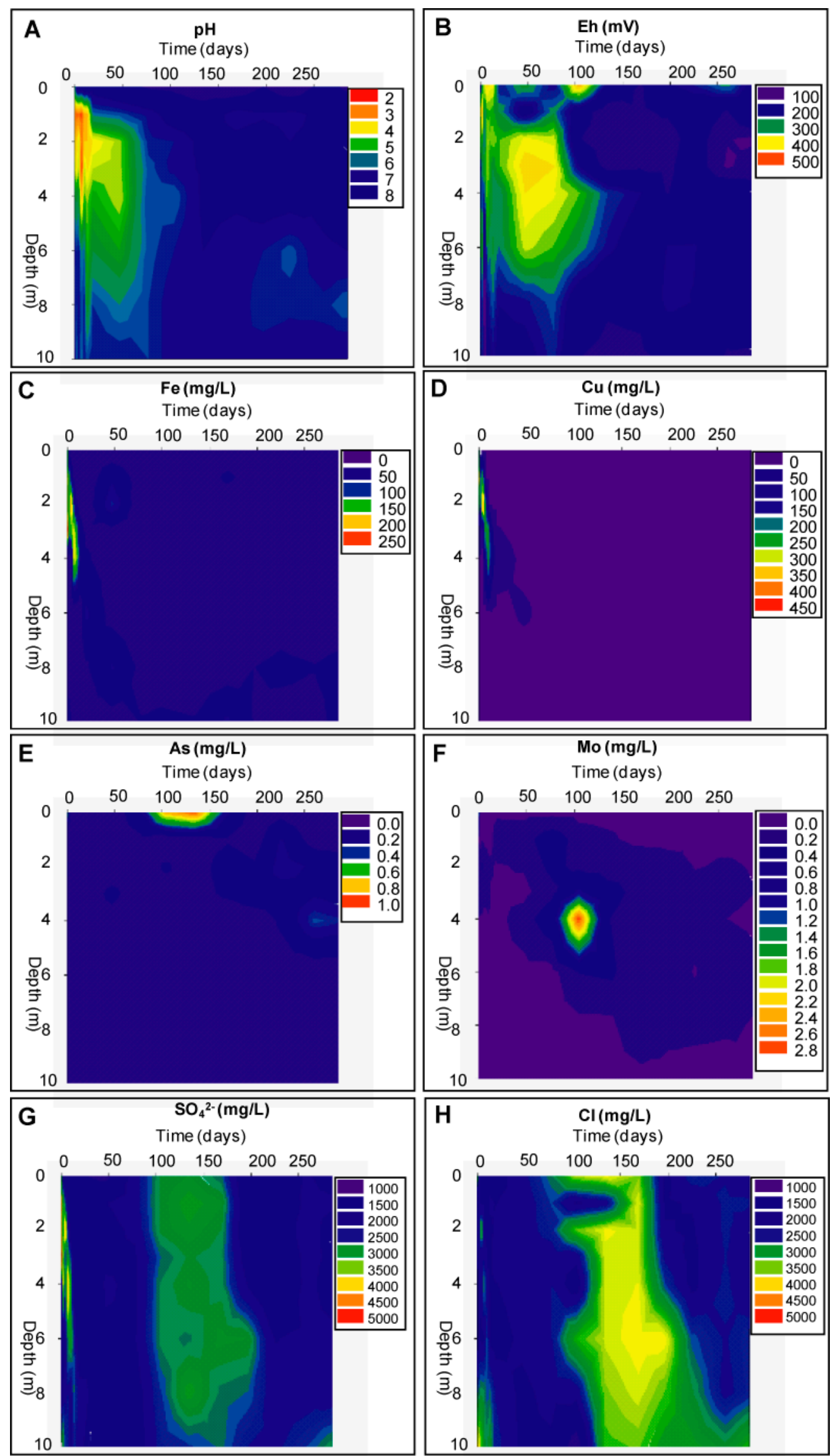


Geochemical Evolution in the NC Tailings Stratigraphy over Time

The implementation of the wetland on the former oxidation zone led immediately to a decrease of the $\mathrm{pH}$ down to 2.4 and an increase of the metal concentrations in solution due to the dissolution of efflorescent salts (Figure 3A). This is confirmed by sequential extraction data, which showed a decrease of the concentrations for $\mathrm{Cu}$ and $\mathrm{Zn}$ of exchangeable and/or water-soluble metals present in the tailings just after flooding (Figure 4 and supplementary information). The efflorescent salts at the top of the oxidizing tailings were composed by elements liberated during years of oxidation and transported by capillarity towards the surface. The implementation of the wetland dissolved these mainly water-soluble sulfates $[19,20]$ and chlorides and transferred them into solution.

From day 7, the $\mathrm{pH}$ began to increase in the oxidation zone from 2.4 stabilizing at 6.5 after five months (Figure 3A). The increase of $\mathrm{pH}$ and the change to more reducing conditions $(200 \mathrm{mV})$ led to a decrease of most metals in solution in both the oxidation zone and the underlying primary zone. After 100 days of remediation, the concentrations of dissolved heavy metals decreased according to the depth up to: Fe (79.5\%-99.4\%), Mn (94.6\%-99.9\%), and Zn (96.1\%-99.6\%). Cu was below detection limit as well as Al, and Ni. Mg had concentrations between 114 and $149 \mathrm{mg} / \mathrm{L}$, which were close to the concentrations of the water used for flooding $(100 \mathrm{mg} / \mathrm{L})$. At the end of the 270 days remediation experiment, only Fe and Mn were mobile at high concentrations (up to $41 \mathrm{mg} / \mathrm{L}$ and $2 \mathrm{mg} / \mathrm{L}$, respectively), most likely as a result of reductive dissolution of $\mathrm{Fe}$ and $\mathrm{Mn}$ hydroxides from the oxidation zone to the primary zone [21].

The Fe concentration in the saturated low $\mathrm{pH}$ oxidation zone was $176 \mathrm{mg} / \mathrm{L}$ at $1 \mathrm{~m}$ depth before remediation. With the flooding, the infiltration of neutral oxygenated water resulted in the precipitation of Fe(III) hydroxides through hydrolysis of Fe(III), decreasing iron concentrations in solution to $1.3 \mathrm{mg} / \mathrm{L}$ after 90 days. Additionally, due to the increase of the hydraulic gradient during flooding, the Fe(II) plume, which was underlying the oxidation front, was pushed downwards to higher $\mathrm{pH}$ conditions. This induced the oxidation of $\mathrm{Fe}(\mathrm{II})$ to $\mathrm{Fe}(\mathrm{III})$ and subsequent hydrolysis and precipitation as $\mathrm{Fe}(\mathrm{III})$ hydroxides.

The precipitation of iron hydroxides after flooding is supported by the saturation index calculation with the PHREEQC code [22], showing that the solution was oversaturated with respect to ferrihydrite $(\mathrm{SI}=2.42)$ and goethite $(\mathrm{SI}=5.12)$. In the sequential extractions, Fe concentrations increased from $0.27 \mathrm{wt} \%$ before remediation to $0.94 \mathrm{wt} \%$ after flooding in the fraction of the Fe(III) hydroxides in the top layer (Figure 4B). As the tailings were already oxidizing, the metal removal was $\mathrm{pH}$ controlled. With the implementation of the wetland using neutral water, the $\mathrm{pH}$ raised and metals were adsorbed on $\mathrm{Fe}(\mathrm{III})$ hydroxide $[23,24]$ and/or co-precipitated $[6,25,26]$.

Fe removal from solution is also due to formation of sulfide when reducing conditions were available after 19 days. The sulfide fraction of $\mathrm{Fe}$ in the sequential extractions increased from 1.38 to $2.73 \mathrm{wt} \%$ during the remediation process (Figure $4 \mathrm{C}$ ). 
Figure 4. Result of sequential extractions from samples of the Northern Cell during the remediation process.

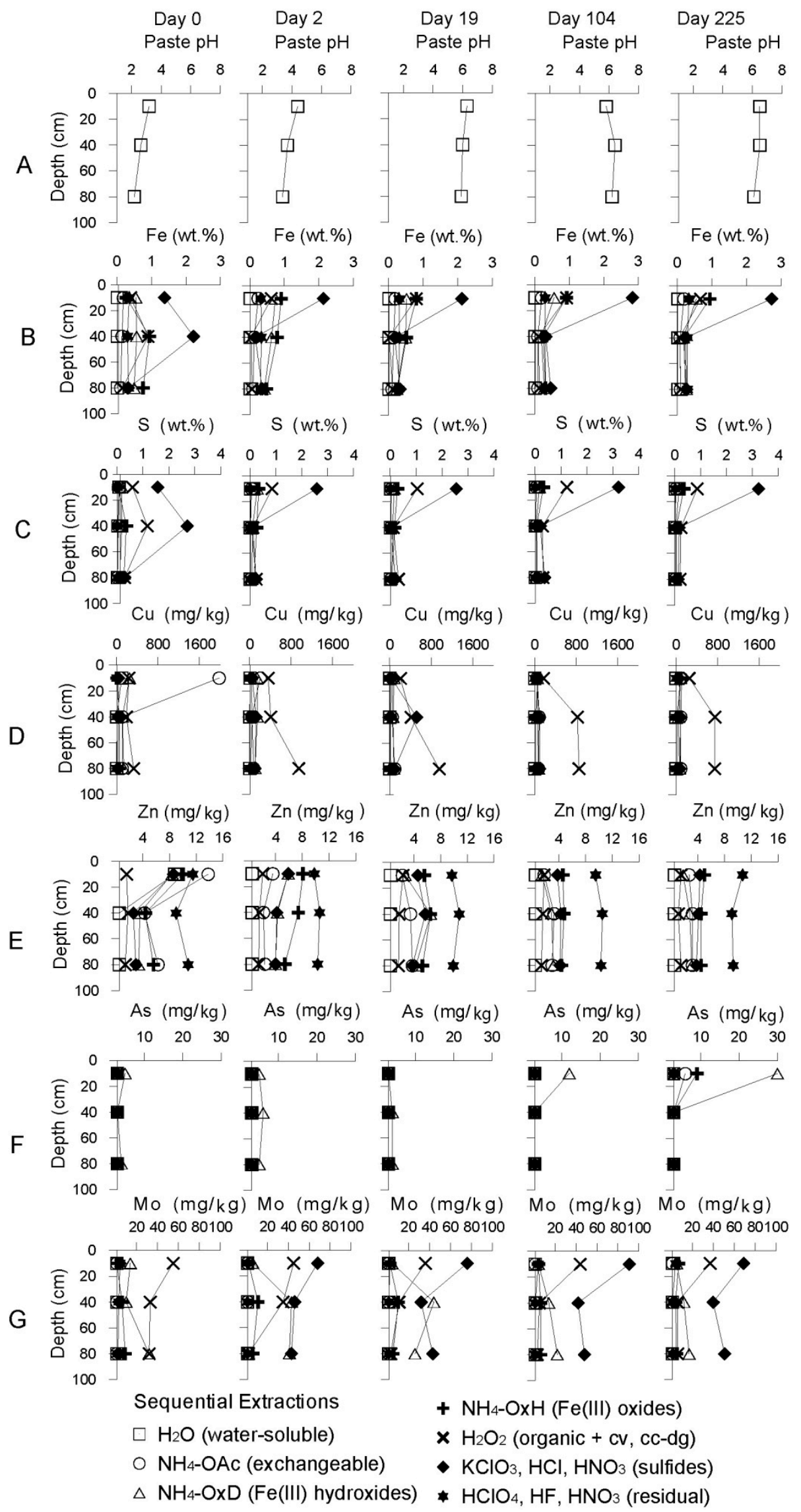


$\mathrm{Cu}$ concentrations were high in the oxidation zone before the remediation (up to $350 \mathrm{mg} / \mathrm{L} \mathrm{Cu}$ ) due to advanced sulfide oxidation (Figure 3D). When the remediation process was initiated the $\mathrm{pH}$ increased and the concentrations decreased to $200-250 \mathrm{mg} / \mathrm{L}$. Due to the increased hydraulic gradient installed by the remediation process, a metal-rich plume was pushed downwards to higher $\mathrm{pH}$ and more reducing conditions (Figure 3D). After Day 19 the redox environment started to be reducing at the depth where the $\mathrm{Cu}$ plume was located (1-4 m depth). This change initiated the fixation of $\mathrm{Cu}$ by organic matter and reduction to sulphides and could be quantified by the sequential extraction data (Figure 4D): an increase in the fraction of the $\mathrm{Cu}$ in the $\mathrm{H}_{2} \mathrm{O}_{2}$ leach from 191 up to $824 \mathrm{mg} / \mathrm{kg}$ at $40 \mathrm{~cm}$ depth and from 330 up to $1240 \mathrm{mg} / \mathrm{kg}$ at $80 \mathrm{~cm}$ was observed. As a consequence, $\mathrm{Cu}$ was removed from water and its concentration decreased below the detection limit at the end of the experiment. The precipitation of iron oxides/hydroxides discussed above participated also to a minor extent to copper removal, supported by the sequential extraction data, which showed that the $\mathrm{Cu}$ associated to the $\mathrm{Fe}(\mathrm{III})$ hydroxide fraction increased from $4 \mathrm{mg} / \mathrm{kg}$ before remediation to $87 \mathrm{mg} / \mathrm{kg}$ after flooding (Figure 4D). Zn which concentration decreased from $12.9 \mathrm{mg} / \mathrm{L}$ to a value below detection limit in solution had the same behavior as $\mathrm{Cu}$. It formed a plume downward and was precipitated as secondary sulfides [27].

The high $\mathrm{SO}_{4}{ }^{2-}$ concentrations associated with sulfide oxidation in the upper part of the sediment column decreased from $4167 \mathrm{mg} / \mathrm{L}$ to 1829 after one month of remediation, mainly due to dilution (Figure $3 \mathrm{G}$ ). The decreasing trend of sulfate in the late remediation experiment is interpreted as a result of sulfide precipitation subsequent to sulfate reduction by sulfate reducing bacteria (SRB). The $S_{\text {sulfide }}$ in the tailings increased from $1.57 \%$ to $3.24 \%$ during the remediation process (Figure $4 \mathrm{C}$ ). Moreover, the microbiological study of the Bahía de Ite remediation experiment (will be published elsewhere), reported the appearance of sulfate reducing bacteria (SRB) in the late state of remediation process (after 104 days). The stable concentrations around $1800 \mathrm{mg} / \mathrm{L} \mathrm{SO}_{4}{ }^{2-}$ in the whole stratigraphy are controlled by the gypsum solubility (SI gypsum $=-0.47$ ).

Chloride had relatively constant concentrations close to the inflowing water from the wetland between 1500 and $2000 \mathrm{mg} / \mathrm{L}$, in the whole profile, peaking at $3500 \mathrm{mg} / \mathrm{L}$ at $10 \mathrm{~m}$ depth (Figure $3 \mathrm{H}$ ), where the seawater/freshwater interface is present. Na showed the same behavior as $\mathrm{Cl}$.

From the third to the fifth month after remediation started, the chloride, sodium and sulfate concentrations increased to around 3000 to $4000 \mathrm{mg} / \mathrm{L}$ through the whole profile (Figure $3 \mathrm{G}, \mathrm{H}$ ). The water in-flow from the Locumba River can vary extremely during the year (depending on the seasons). When the water-level in the wetland was about $1 \mathrm{~m}$ above sea level as maximum, the freshwater/seawater interface can be assumed at $40 \mathrm{~m}$ depth according to the Ghyben-Herzberg approximation [10]. An average decrease to $0.5 \mathrm{~m}$ of the wetland water level was observed every summer (dry season) during three years of monitoring. This decrease resulted in an approximate rise of this interface to $20 \mathrm{~m}$ depth in the old wetland and, consequently, in a lower hydraulic gradient. Therefore, the change in salinity in the tailings pore water during the summer months can be seen as a result of the intrusion of the freshwater-seawater transition zone into the tailings deposit. This interpretation is supported by isotopic analysis. During this period of $\mathrm{Na}$ and $\mathrm{Cl}$ increase, the $\delta^{34} \mathrm{~S}$ values were at $\delta^{34} \mathrm{~S}=14.70 \%$ to $15.82 \% \mathrm{~V}$-CDT closer to seawater value $\delta^{34} \mathrm{~S}=20 \%$ to $21 \% \mathrm{~V}$-CDT. The $\delta^{34} \mathrm{~S}$ values on samples taken before and after this increase were lighter, at $12.04 \%$ and $13.10 \%$, peaking at $15.15 \%$ V-CDT only for the deepest samples, which still had marine influence [10]. 
Arsenic showed concentrations of $0.02 \mathrm{mg} / \mathrm{L}$ in the pore water of the oxidation zone and relatively low concentration $(0.15 \mathrm{mg} / \mathrm{L})$ shortly after the remediation started, as the tailings contain very low concentrations (mean of $4 \mathrm{mg} / \mathrm{kg} \mathrm{As}$ ) of arsenic (Figure 4F). After 100 and until 150 days a strong increase in the upper part and in the water cover of the cell culminated at $0.9 \mathrm{mg} / \mathrm{L}$ arsenic. Since the tailings material is not the source of arsenic in this system, this liberation can be explained as followed: as discussed above, the remediation process initiated the precipitation of $\mathrm{Fe}(\mathrm{III})$ hydroxides in the wetland. These Fe(III) hydroxides had a high sorption capacity for the naturally incoming arsenic from the Locumba water. Therefore, it acts as a filter for arsenic, resulting in low concentration in the wetland water after eight days. This is confirmed by the sequential extraction data, which show an increase of As in the Fe(III) hydroxide fraction of up to $800 \%$ between the start and the end of the remediation experiment (Figure $4 \mathrm{~F}$ ). Then, during the dry season, increased concentration of $\mathrm{Cl}$ and $\mathrm{SO}_{4}$, due to increasing seawater infiltrations into the deposit, compete with As on the sorption sites (e.g., [28]) and triggered a the release of arsenic into solution. This arsenic liberation mechanism resulted in an increase of the concentration of up to $0.3 \mathrm{mg} / \mathrm{L}$ after 6 months (Figure 3E). The liberated As migrated downwards $(0.3 \mathrm{mg} / \mathrm{L} \mathrm{As})$, reaching $4 \mathrm{~m}$ depth after seven months' remediation.

Mo concentrations in the solution increased over time from 0.05 to $0.2 \mathrm{mg} / \mathrm{L}$ after three months in the oxidation zone due to $\mathrm{pH}$ increase and more reducing conditions, which released the formerly adsorbed Mo to the secondary Fe(III) hydroxides in the oxidation zone [2]. As a consequence, a plume (of up to $2.8 \mathrm{mg} / \mathrm{L}$ ) was forming downward at $4 \mathrm{~m}$ depth (Figure 3F). At the end of the remediation experiment, Mo concentration in solution was close to or below the detection limit due probably to co-precipitation, as reported in other wetlands [29].

\subsubsection{The Delta Area Remediation Cell (DC)}

\section{Starting Conditions before the Remediation}

In the delta remediation cell, the $\mathrm{pH}$ of the vadose zone $(0-1 \mathrm{~m})$ ranged between 3.0 and 3.1 with a redox potential around $578 \mathrm{mV}$ (Table 3) before the remediation started. The heavy metal concentrations in pore water were up to $2299 \mathrm{mg} / \mathrm{L} \mathrm{Fe}, 4448 \mathrm{mg} / \mathrm{L} \mathrm{Al}, 1035 \mathrm{mg} / \mathrm{L} \mathrm{Cu}, 6138 \mathrm{mg} / \mathrm{L} \mathrm{Mg}$, $716 \mathrm{mg} / \mathrm{L} \mathrm{Mn}, 6.77 \mathrm{mg} / \mathrm{L} \mathrm{Ni}$, and $213 \mathrm{mg} / \mathrm{L} \mathrm{Zn}$. Arsenic and sulfate concentrations were $0.15 \mathrm{mg} / \mathrm{L}$ and 33,270 mg/L, respectively (Table 3). At $1 \mathrm{~m}$ depth, the heavy metals concentrations were (Table 3): $703 \mathrm{mg} / \mathrm{L} \mathrm{Fe}, 3.72 \mathrm{mg} / \mathrm{L} \mathrm{Al}, 0.26 \mathrm{mg} / \mathrm{L} \mathrm{Cu}, 166 \mathrm{mg} / \mathrm{L} \mathrm{Mg}, 62.5 \mathrm{mg} / \mathrm{L} \mathrm{Mn}, 0.46 \mathrm{mg} / \mathrm{L} \mathrm{Ni}, 1.20 \mathrm{mg} / \mathrm{L}$ $\mathrm{Zn}$, and sulfate was $3483 \mathrm{mg} / \mathrm{L}$. Na concentrations reached $1600 \mathrm{mg} / \mathrm{L}$ in the oxidation zone, possibly due to silicate alteration and jarosite dissolution.

From $3 \mathrm{~m}$ depth, the $\mathrm{pH}$ increased up to 6.2 with reducing conditions $( \pm 200 \mathrm{mV})$, leading to a decrease of the metal concentrations in the pore water (Table 3). Fe concentrations decreased, but were still high (146 to $634 \mathrm{mg} / \mathrm{L})$. Al, $\mathrm{Cu}$, and $\mathrm{Ni}$ were near the detection limit, $\mathrm{Mg}$ decreased to around $120 \mathrm{mg} / \mathrm{L}, \mathrm{Mn}$ to $12.8-69 \mathrm{mg} / \mathrm{L}$, and $\mathrm{Zn}$ to $7.63 \mathrm{mg} / \mathrm{L}$. $\mathrm{Cl}$ and $\mathrm{Na}$ showed concentration between 700 and $2000 \mathrm{mg} / \mathrm{L}$.

Before the remediation, arsenic concentration was low in the $1 \mathrm{~m}$ depth oxidation zone $(0.02 \mathrm{mg} / \mathrm{L}$, Table 3), due to the sorption on Fe (III) hydroxides [30]. It was higher in the primary zone (up to $0.25 \mathrm{mg} / \mathrm{L}$ ), but still lower than the natural background of the Locumba river water (around $0.5 \mathrm{mg} / \mathrm{L}$ ) [10]. 
Table 3. Geochemistry of the piezometers in the delta cell before the start of the remediation experiment.

\begin{tabular}{|c|c|c|c|c|c|c|c|c|c|c|}
\hline Samples & $\begin{array}{l}\text { Depth } \\
(\mathrm{m})\end{array}$ & pH & $\begin{array}{c}\mathrm{EC} \\
(\mathrm{ms} / \mathrm{cm})\end{array}$ & $\begin{array}{c}\text { Eh } \\
(\mathbf{m V})\end{array}$ & $\begin{array}{c}\text { Alkalinity } \\
(\mathrm{mg} / \mathrm{L} \mathrm{CaCO})\end{array}$ & $\begin{array}{c}\mathrm{Al} \\
(\mathrm{mg} / \mathrm{L})\end{array}$ & $\begin{array}{c}\mathrm{As} \\
(\mathrm{mg} / \mathrm{L})\end{array}$ & $\begin{array}{c}\mathrm{Ca} \\
(\mathrm{mg} / \mathrm{L}) \\
\end{array}$ & $\begin{array}{c}\mathrm{Cl} \\
(\mathrm{mg} / \mathrm{L})\end{array}$ & $\begin{array}{c}\mathrm{Co} \\
(\mathrm{mg} / \mathrm{L}) \\
\end{array}$ \\
\hline SI7SI & 0.2 & 3.0 & 23.50 & 578 & $<1.5$ & 4448 & 0.15 & 980 & $\mathrm{~N} / \mathrm{A}$ & 9.80 \\
\hline SI7SII & 0.55 & 3.1 & 5.11 & 566 & $<1.5$ & 1653 & 0.10 & 466 & N/A & 5.26 \\
\hline SI7P1 & 1 & 3.1 & 2.49 & 533 & $<1.5$ & 3.72 & 0.02 & 552 & N/A & 0.37 \\
\hline SI7P2 & 2 & 4.2 & 6.05 & 410 & $<1.5$ & 0.87 & 0.13 & 551 & N/A & 0.15 \\
\hline SI7P3 & 3 & 6.2 & 7.01 & 105 & 165 & $<0.05$ & 0.25 & 632 & 1,009 & BDL \\
\hline SI7P4 & 4 & 6.0 & 6.60 & 243 & 105.15 & $<0.05$ & 0.15 & 539 & 545 & 0.44 \\
\hline SI7P6 & 6 & 5.4 & 5.00 & 305 & 13.8 & $<0.05$ & 0.16 & 380 & 476 & 0.68 \\
\hline SI7P8 & 8 & 5.7 & 5.20 & 265 & 62.95 & 1.91 & 0.10 & 404 & 510 & 0.73 \\
\hline SI7P10 & 10 & 5.2 & 6.11 & 359 & 38.7 & $<0.05$ & $<0.002$ & 517 & 965 & 1.37 \\
\hline Samples & $\begin{array}{l}\text { Depth } \\
\text { (m) }\end{array}$ & $\begin{array}{c}\mathrm{Cu} \\
(\mathrm{mg} / \mathrm{L})\end{array}$ & $\begin{array}{c}\mathrm{Fe} \\
(\mathrm{mg} / \mathrm{L})\end{array}$ & $\begin{array}{c}\mathrm{K} \\
(\mathrm{mg} / \mathrm{L})\end{array}$ & $\begin{array}{c}\mathrm{Mg} \\
(\mathrm{mg} / \mathrm{L})\end{array}$ & $\begin{array}{c}\mathrm{Mn} \\
(\mathrm{mg} / \mathrm{L})\end{array}$ & $\begin{array}{c}\text { Mo } \\
(\mathrm{mg} / \mathrm{L}) \\
\end{array}$ & $\begin{array}{c}\mathrm{Na} \\
(\mathrm{mg} / \mathrm{L})\end{array}$ & $\begin{array}{c}\mathrm{SO}_{4} \\
(\mathrm{mg} / \mathrm{L}) \\
\end{array}$ & $\begin{array}{c}\mathrm{Zn} \\
(\mathrm{mg} / \mathrm{L})\end{array}$ \\
\hline SI7SI & 0.2 & 1,035 & 2,299 & 3.58 & 6,138 & 716 & $<0.04$ & 1,650 & 33,270 & 213 \\
\hline SI7SII & 0.55 & 335 & 2,001 & 0.91 & 1,631 & 132 & $<0.04$ & 319 & 19,560 & 10.1 \\
\hline SI7P1 & 1 & 0.26 & 703 & 34.2 & 276 & 62.5 & $<0.04$ & 692 & 3,483 & 1.20 \\
\hline SI7P2 & 2 & 1.37 & 615 & 87.9 & 120 & 13.2 & $<0.04$ & 733 & 2,554 & 2.53 \\
\hline SI7P3 & 3 & $<0.005$ & 146 & 78.9 & 256 & 12.8 & 0.05 & 634 & 2,635 & 0.07 \\
\hline SI7P4 & 4 & $<0.005$ & 383 & 89.9 & 393 & 54.8 & $<0.04$ & 399 & 3,612 & 10.1 \\
\hline SI7P6 & 6 & 0.02 & 598 & 52.5 & 204 & 28.8 & $<0.04$ & 325 & 2,835 & 5.43 \\
\hline SI7P8 & 8 & 0.28 & 634 & 58.7 & 193 & 33.9 & $<0.04$ & 377 & 2,873 & 3.16 \\
\hline SI7P10 & 10 & $<0.005$ & 412 & 107 & 345 & 69.4 & $<0.04$ & 727 & 3,483 & 7.63 \\
\hline
\end{tabular}

Evolution of the Aquatic Geochemistry in the Surface Waters of the Remediation Cell DC

The water (from the Locumba river) used for the flooding of the remediation cell had $\mathrm{pH}$ of 7.3, Eh of $420 \mathrm{mV}, 133 \mathrm{mg} / \mathrm{L}$ alkalinity as $\mathrm{CaCO}_{3}, 433 \mathrm{mg} / \mathrm{L} \mathrm{Cl}, 300 \mathrm{mg} / \mathrm{L} \mathrm{Na}, 429 \mathrm{mg} / \mathrm{L} \mathrm{SO}_{4}{ }^{2-}, 0.27 \mathrm{mg} / \mathrm{L}$ As and $2.6 \mathrm{mg} / \mathrm{L} \mathrm{DOC}$ at the water inflow (Figure 5). The concentrations of heavy metals were below detection limit.

Immediately after the flooding, these values did not vary a lot, except for sulfate, which increased to $613 \mathrm{mg} / \mathrm{L}$. Two days after flooding the $\mathrm{pH}$ of the water cover decreased strongly to 2.7 , as well as the alkalinity and the Eh increased to $646 \mathrm{mV}$ (Figure 5). Then, the concentrations of the heavy metals started to increase, reaching at day 4: $8.9 \mathrm{mg} / \mathrm{L} \mathrm{Fe}, 265 \mathrm{mg} / \mathrm{L} \mathrm{Al}, 457 \mathrm{mg} / \mathrm{L} \mathrm{Cu}, 238 \mathrm{mg} / \mathrm{L} \mathrm{Mn}, 19 \mathrm{mg} / \mathrm{L}$ Zn (Figure 5). Sodium, chloride and sulfate increased up to $734 \mathrm{mg} / \mathrm{L}, 1621 \mathrm{mg} / \mathrm{L}$ and $5385 \mathrm{mg} / \mathrm{L}$, respectively (Figure 5). This is explained by the dissolution of the efflorescent salts, which were abundant present at the surface of the remediation cell due to the finer grain size and subsequent stronger capillary transport as in the NC. Seven days after the wetland construction, the $\mathrm{pH}$ of the surface water started to increase due to the consumption of the acidity by the alkalinity $(133 \mathrm{mg} / \mathrm{L}$ as $\mathrm{CaCO}_{3}$ ) of the inflowing water, but also due to the dilution effect of the continuous flooding. The water flow into the remediation cell was controlled by an outflow pipe at $50 \mathrm{~cm}$ height in the dikes, discharging the excess of water to avoid breaking the dikes. As a consequence of increasing $\mathrm{pH}$ (7.1 at day 15) and increase of alkalinity, most of the heavy metals in the water cover were close or 
below the detection limit after 14 days of flooding (Figure 5). This decrease of metal concentration in the water cover with increasing $\mathrm{pH}$ can be explained by metal precipitation as oxide and hydroxide. Alkalinity, sodium, sulfate and chloride showed a cyclic behavior after the first peak due to dissolution of the efflorescent salts. Alkalinity showed a drop in the dry seasons, suggesting increased sulfide oxidation. Sodium, chloride, and sulfate showed an increase during the dry seasons, which correlated with an increase of the arsenic concentrations (Figure 5).

Figure 5. Evolution of hydrogeochemistry in the water cover of the delta cell during the remediation process. In the time-scale axes, the arrow (day 0 ) corresponds to the water sample taken at the start of the experiments before flooding.
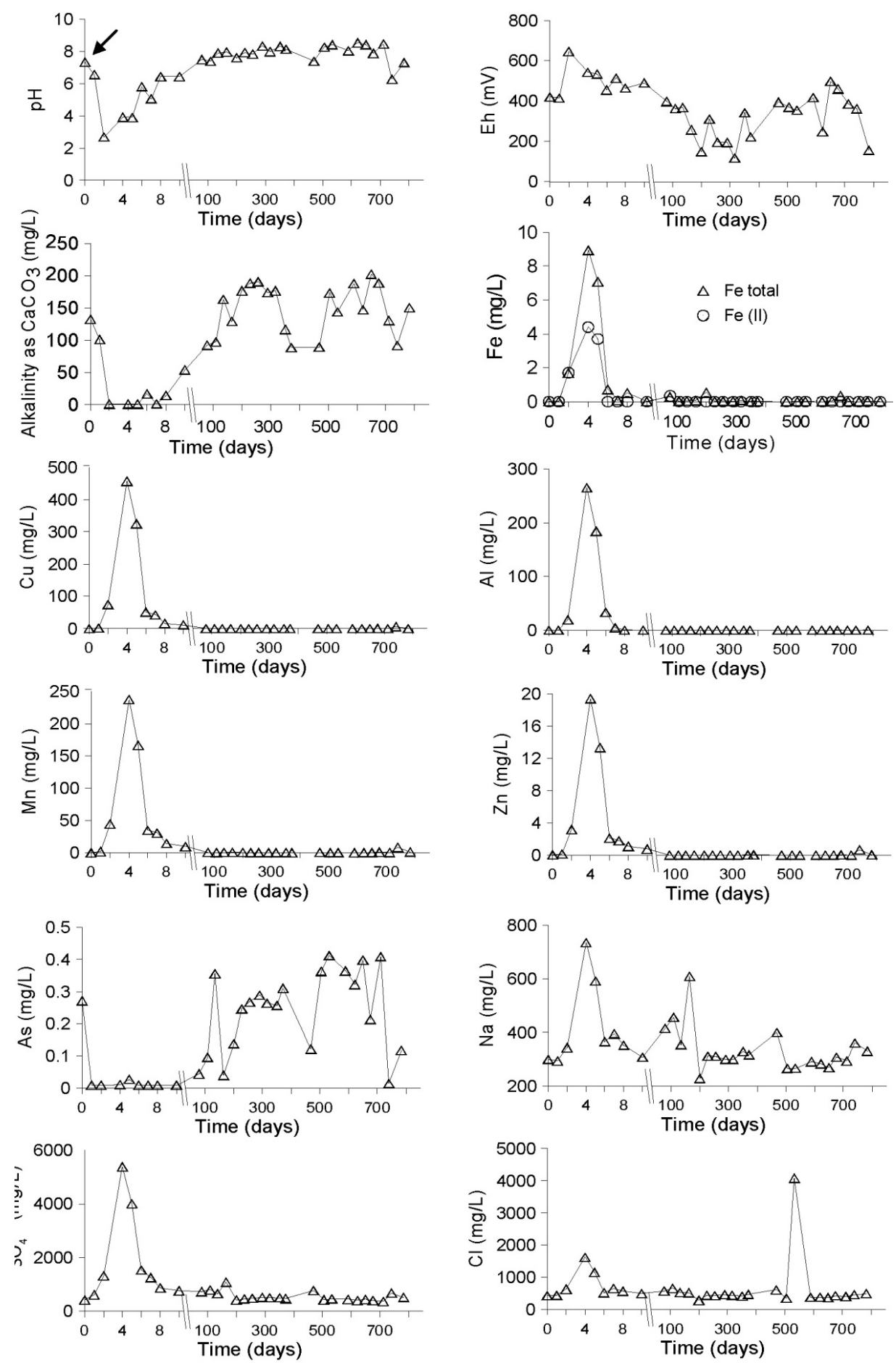
Arsenic concentration in the water cover first decreased down below the detection limit in contact with the iron hydroxide secondary minerals. After seven days, it increased up to $0.4 \mathrm{mg} / \mathrm{L}$ as a consequence of the release of As formerly adsorbed on iron hydroxides. Additionally, the increased $\mathrm{SO}_{4}{ }^{2-}$ and $\mathrm{Cl}^{-}$concentrations promoted the liberation of As from the $\mathrm{Fe}(\mathrm{III})$ hydroxides. When alkalinity dropped, i.e., sulfide oxidation increased, the As concentration decreased, suggesting sorption to newly formed $\mathrm{Fe}$ (III) hydroxides through sulfide oxidation. A general trend of decrease for the $\mathrm{Na}^{+}, \mathrm{Cl}^{-}$and $\mathrm{SO}_{4}{ }^{2-}$ peak concentrations was also observed, most likely through dilution effects.

Geochemical Evolution in the DC Tailings Stratigraphy over Time

After the implementation of the wetland, $\mathrm{pH}$ remained acidic (3.1) at $1 \mathrm{~m}$ depth in the oxidation zone (Figure 6A). Eh decreased at the beginning down to $308 \mathrm{mV}$ and then was fluctuating between 300 and $500 \mathrm{mV}$ (Figure 6B). The concentrations of metals in solution increased up to $46 \% \mathrm{Fe}, 7900 \% \mathrm{Cu}$, $174 \% \mathrm{Al}$, and $15 \% \mathrm{Zn}$ in the first 30 days of the remediation experiment. $\mathrm{SO}_{4}{ }^{2-}$ and $\mathrm{Cl}^{-}$increased up to $43 \%$ and $104 \%$, respectively (Figure $6 \mathrm{G}, \mathrm{H}$ ). This can be explained by the seepage of water from the water cover (rich in metals after the flooding) into the former $1 \mathrm{~m}$ vadose unsaturated oxidation zone of the tailings. This infiltration dissolved also the elements liberated during years in the oxidation zone, increasing additionally their concentration in solution.

Starting 45 days after flooding, the $\mathrm{pH}$ showed a slight increasing trend, reaching 4.4 after 465 days of remediation (Figure 6A). During the same time period the element concentrations in solution showed a decreasing trend. Calculated with respect to the maximum value measured after flooding, these concentrations dropped down to $96 \%$ for $\mathrm{Fe}$, and $51 \%$ for $\mathrm{Cu}$ around 15.5 months after remediation started. $\mathrm{Al}, \mathrm{Mn}$, and $\mathrm{Zn}$ decreased to $88 \%, 97 \%$, and $95 \%$, respectively. Sulfate and chloride were fluctuating during this time with a decreasing trend maintaining value close to the inflowing water (Figure 6G,H). The iron concentration increased up to $4432 \mathrm{mg} / \mathrm{L}$ after flooding due to dissolution of efflorescent salts (Figure 6C).

With the installation of the wetland, water seepage induced the increase of $\mathrm{pH}$ from 3 to 4.4, triggering $\mathrm{Fe}$ (III) hydroxide precipitation, removing this metal from solution down to concentration $179 \mathrm{mg} / \mathrm{L}$ after 465 days (Figure 6C). The saturation indexes showed oversaturation with respect to goethite $(\mathrm{SI}=4.01)$ and ferryhydrite $(\mathrm{SI}=1.31)$. The sequential extraction data showed that the Fe(III) hydroxides and Fe(III) oxide fractions were increasing over time (Figure 7B). The sulfide fraction of Fe was also increasing in the former oxidation zone during the remediation process, suggesting precipitation of a secondary sulfide, which participated in Fe removal (Figure 7B). Total iron in the tailings matrix increased from $3.58 \%$ to $5.01 \%$. Mn showed a similar behavior as Fe and decreased from 323 to $10 \mathrm{mg} / \mathrm{L}$ after 15.5 months of remediation, due to formation of Mn oxides and hydroxides which can also act as adsorbants and co-precipitate other metals such as $\mathrm{Zn}, \mathrm{Co}, \mathrm{Ni}, \mathrm{Cu}$ [31].

$\mathrm{Cu}$ was dissolving from efflorescent salts (e.g., chalcanthite, eriochalcite) and increasing to concentration in solution up to $20.8 \mathrm{mg} / \mathrm{L}$ at $1 \mathrm{~m}$ depth just after the flooding. Copper was present in the water-soluble and exchangeable fractions at day 3 (Figure 7D). Once the cell completely flooded, the $\mathrm{Cu}$ plume was pushed slowly downward, where the installation of more reducing conditions led to adsorption onto organic matter, decreasing the concentration in solution to $1.66 \mathrm{mg} / \mathrm{L}$ after one year of remediation. This was confirmed by sequential extraction data showing increase of organic related $\mathrm{Cu}$ 
fraction from 713 to $1020 \mathrm{mg} / \mathrm{kg}$ at $1 \mathrm{~m}$ during the remediation process (Figure 7D). Zn had a similar behavior as $\mathrm{Cu}$, showing decreasing concentration in solution from $47.3 \mathrm{mg} / \mathrm{L}$ to 1.73 after 465 days, whereas its concentration in the tailings matrix was increasing in the exchangeable, organic and Fe(III) hydroxide fractions (Figure 7E). This suggested $\mathrm{Zn}$ removal from solution by sorption, co-precipitation, and sulfide formation [27].

Figure 6. Evolution of hydrogeochemistry in the piezometer nest of the delta cell during the remediation process.
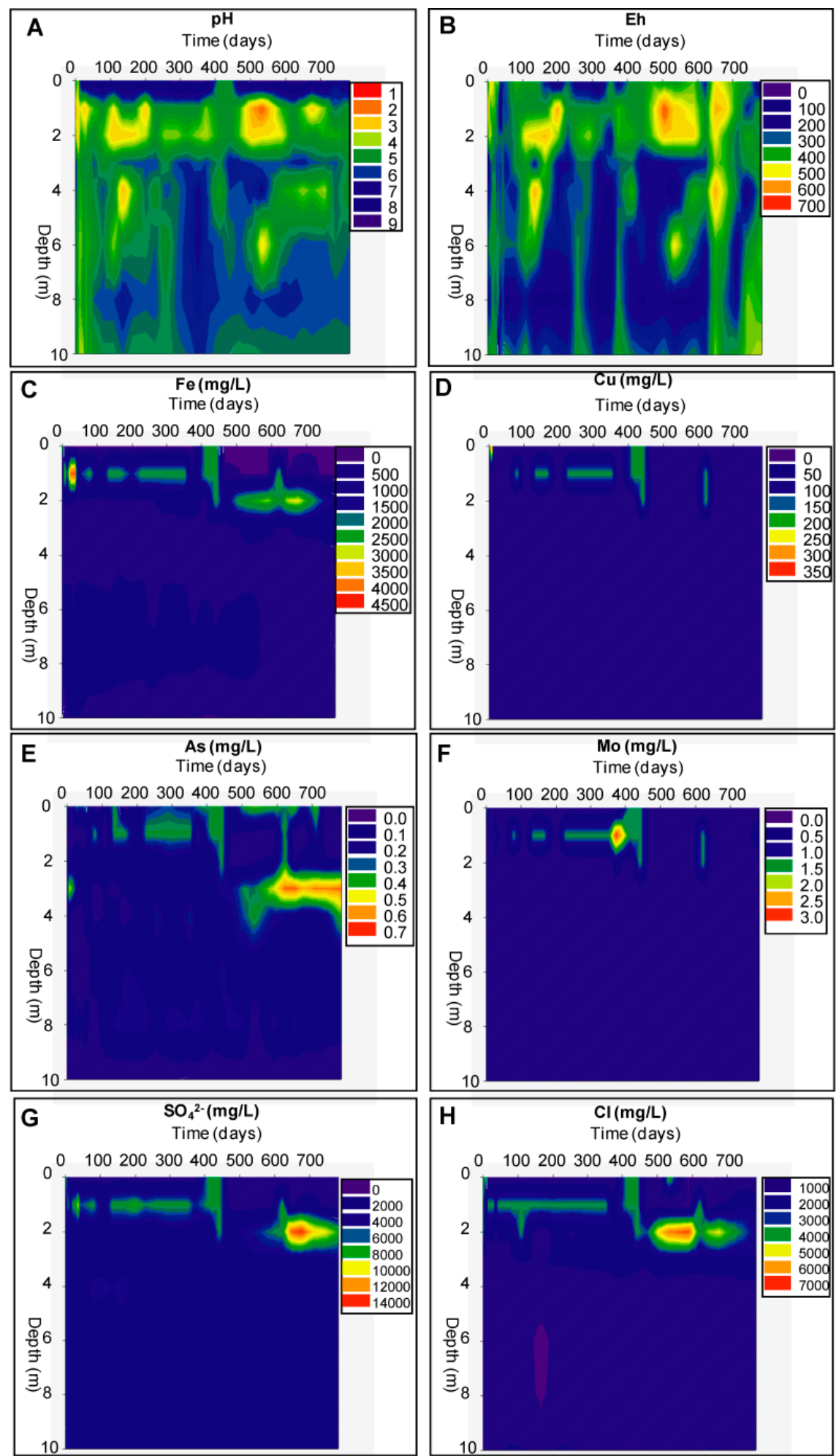
Figure 7. Result of sequential extractions from samples of the delta cell during the remediation process. For Arsenic (F), the scale at day 593 is different for better visibility.

A

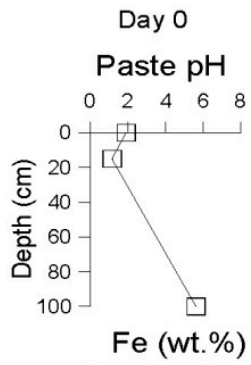

$\mathrm{B}$

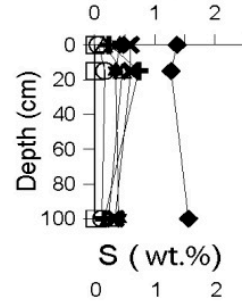

C

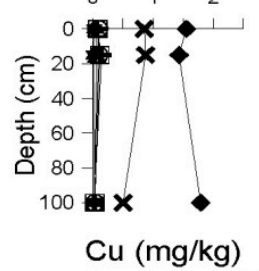

$0 \quad 1000 \quad 2000$

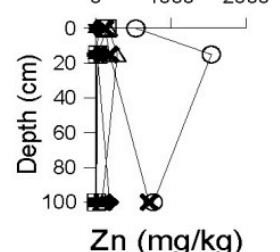

D

$\begin{array}{llll}0 & 40 & 80 & 120\end{array}$

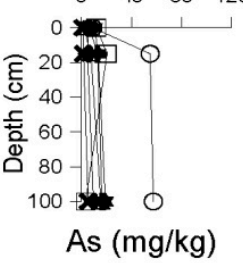

$\begin{array}{lllll}4 & 8 & 12 & 16 & 20\end{array}$

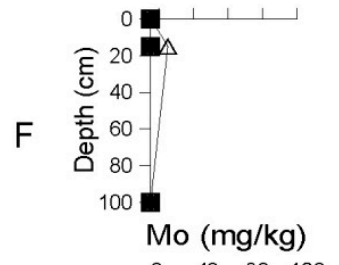

$\begin{array}{llll}0 & 40 & 80 & 120\end{array}$

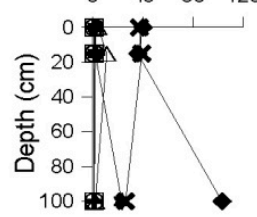

Day 3

Paste $\mathrm{pH}$

$\begin{array}{lllll}0 & 246\end{array}$

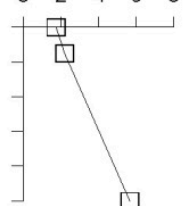

$\mathrm{Fe}(w t . \%)$
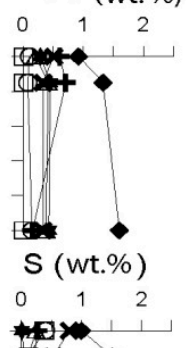

$4 x$
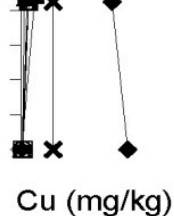

o 10002000
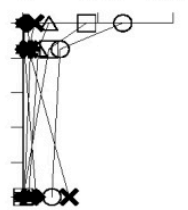

$\mathrm{Zn}(\mathrm{mg} / \mathrm{kg})$

o $40 \quad 80 \quad 120$

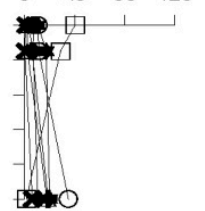

As $(\mathrm{mg} / \mathrm{kg})$
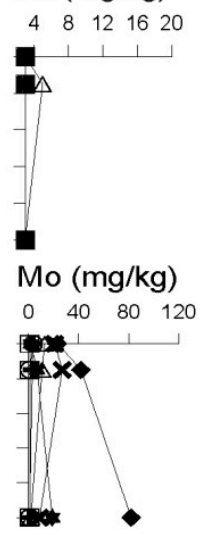

Sequential Extractions

$\square \mathrm{H}_{2} \mathrm{O}$ (water-soluble)

- $\mathrm{NH}_{4}-\mathrm{OAc}$ (exchangeable)

$\triangle \mathrm{NH}_{4}-\mathrm{O} \mathrm{XD}$ ( $\mathrm{Fe}$ (III) hydroxides)
Day 44

Paste $\mathrm{pH}$

$\begin{array}{lllll}0 & 2 & 4 & 6 & 8\end{array}$

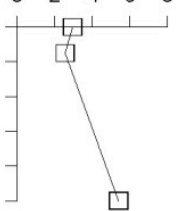

Fe (wt. \%)

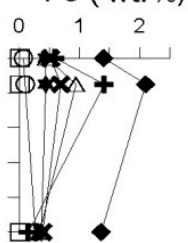

$\mathrm{S}$ (wt.\%)
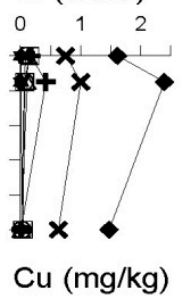

010002000
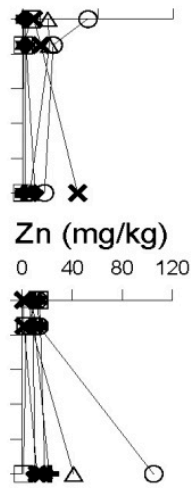

As $(\mathrm{mg} / \mathrm{kg})$

$\begin{array}{lllll}4 & 8 & 12 & 16 & 20\end{array}$

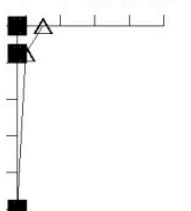

Mo (mg/kg)

$\begin{array}{llll}0 & 40 & 80 & 120\end{array}$

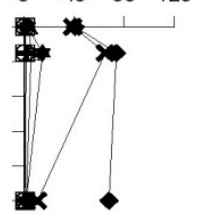

Mo (mg/kg)

$\begin{array}{llll}0 & 40 & 80 & 120\end{array}$
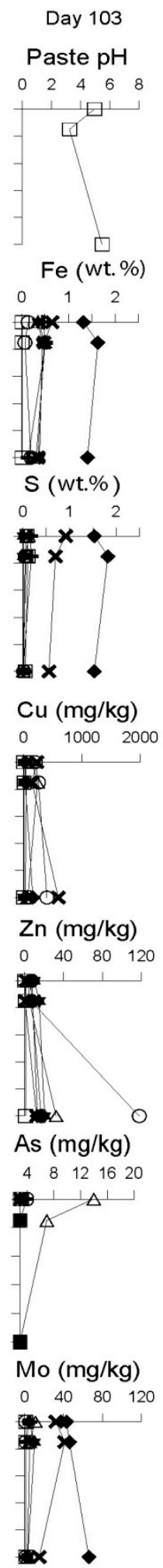

$+\mathrm{NH}_{4}-\mathrm{OxH}$ (Fe(III) oxides)

$\times \mathrm{H}_{2} \mathrm{O}_{2}$ (organic $+\mathrm{cv}, \mathrm{cc}-\mathrm{dg}$ )

- $\mathrm{KClO}_{3}, \mathrm{HCl}, \mathrm{HNO}_{3}$ (sulfides)

- $\mathrm{HClO}_{4}, \mathrm{HF}, \mathrm{HNO}_{3}$ (residual)
Day 593

Paste $\mathrm{pH}$

$\begin{array}{lllll}0 & 2 & 4 & 6 & 8\end{array}$

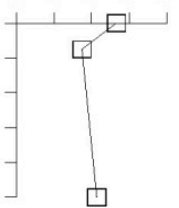

Fe (wt.\%)

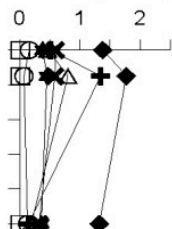

S (wt.\%)

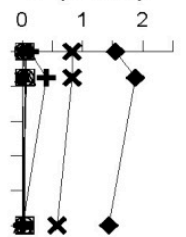

$\mathrm{Cu}(\mathrm{mg} / \mathrm{kg})$

010002000

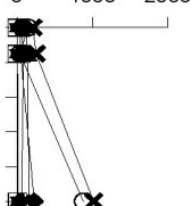

$\mathrm{Zn}(\mathrm{mg} / \mathrm{kg})$

$\begin{array}{llll}0 & 40 \quad 80 \quad 120\end{array}$
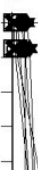

As $(\mathrm{mg} / \mathrm{kg})$
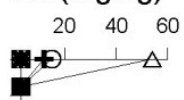

Mo (mg/kg)

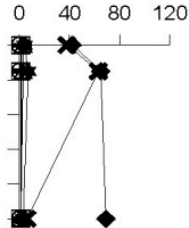


Before remediation, $\mathrm{Cl}^{-}$and $\mathrm{Na}^{+}$, showed concentrations between 600 and $2000 \mathrm{mg} / \mathrm{L}$ and the concentration of $\mathrm{SO}_{4}{ }^{2-}$ was $3483 \mathrm{mg} / \mathrm{L}$ at $1 \mathrm{~m}$ (Figure $6 \mathrm{G}, \mathrm{H}$ ). After the implementation of the wetland $\mathrm{Cl}^{-}, \mathrm{Na}^{+}$, and $\mathrm{SO}_{4}{ }^{2-}$ were increasing up to $3628 \mathrm{mg} / \mathrm{L}, 1019 \mathrm{mg} / \mathrm{L}$, and $7815 \mathrm{mg} / \mathrm{L}$, respectively after 180 days, before decreasing to concentrations close to the natural input from flooding water $(323,195$, and $951 \mathrm{mg} / \mathrm{L}$, respectively) after 550 days (Figure $6 \mathrm{G}, \mathrm{H}$ ). The increase of element concentration observed after remediation is explained by the dissolution of efflorescent salts, which were mainly composed by sulfates and chlorites.

The As concentration was $0.02 \mathrm{mg} / \mathrm{L}$ before the remediation and did not increase in the oxidation zone immediately after flooding (Figure $6 \mathrm{E}$ ). It then increased slightly up to $0.11 \mathrm{mg} / \mathrm{L}$ at day 200 before decreasing again. This general trend of low As concentration in the tailings (compared to the natural background) is related to its affinity to iron hydroxide.

As-rich water was seeping continuously into the tailings, where As was adsorbed in contact with the $\mathrm{Fe}(\mathrm{III})$ hydroxide. The sequential extraction data showed increased As in the Fe(III) hydroxide fraction of up to $1700 \%$ (Figure $7 \mathrm{~F}$ ). At around day 660 after remediation, the As concentration in solution reached $0.63 \mathrm{mg} / \mathrm{L}$ at $3 \mathrm{~m}$ depth (Figure $6 \mathrm{E}$ ). This is interpreted as the result of reductive dissolution of $\mathrm{Fe}(\mathrm{III})$ hydroxides by the installation of reducing conditions after almost two years' remediation, resulting in the release of the formerly adsorbed As [30,32].

Mo was below the detection limit before the remediation. With implementation of the wetland, its concentration in water increased up to $3 \mathrm{mg} / \mathrm{L}$ after one year of remediation, probably due to release from secondary minerals (Figure 6F). The adsorption of Mo on Fe oxide decreased with increasing $\mathrm{pH}$ and the implementation of the wetland favored the Mo desorption [33]. Then Mo concentration in solution decreased below the detection limit as a consequence of secondary sulfides precipitation as suggested by sequential extraction data (Figure $7 \mathrm{G}$ ).

It was observed after around 450 days of the remediation experiment that the $\mathrm{pH}$ decreased again from 4.4 to 1.6 at $1 \mathrm{~m}$ depth and from 4.2 to 3.0 at $2 \mathrm{~m}$. The concentrations of metals and the Eh increased also in the same period. The highest element concentrations located before at the $1 \mathrm{~m}$ oxidation zone were found at $2 \mathrm{~m}$ depth (Figure 6). In general it can be said that most changes were occurring in the upper $3 \mathrm{~m}$ or the profiles of both cells (the former unsaturated zone, which experience the main changes due to $\mathrm{pH}$ increase and change to reducing environment). The heavy metal concentrations were close to, or higher than, concentrations observed in the first days of remediation: up to $3200 \mathrm{mg} / \mathrm{L} \mathrm{Fe}, 10.1 \mathrm{mg} / \mathrm{L} \mathrm{Cu}$, and $2.93 \mathrm{mg} / \mathrm{L} \mathrm{Mo}$, (Figure 6C,D,F). Other metals not represented in the graphs were also increasing up to $14.6 \mathrm{mg} / \mathrm{L} \mathrm{Al}, 11.5 \mathrm{mg} / \mathrm{L} \mathrm{Mn}, 1.8 \mathrm{mg} / \mathrm{L} \mathrm{Zn}$. $\mathrm{Cl}^{-}$and $\mathrm{SO}_{4}{ }^{2-}$ increased also up to 6639 , and $6396 \mathrm{mg} / \mathrm{L}$ respectively (Figure $6 \mathrm{G}, \mathrm{H}$ ). The sulfate concentration reached $13,740 \mathrm{mg} / \mathrm{L}$ at months 22.5 (675 days). This change can be explained by the fact that the remediation cell was completely dry during two months (in summer) from the day 450 due to drought and a landslide in the river "Rio Locumba" flowing into the bay, and the water table dropped down below $2 \mathrm{~m}$ depth (the piezometers at 1 and $2 \mathrm{~m}$ were dry). Due to this drastic drought, and to the desert climate, oxidizing conditions were again available at the top and the liberated elements in the solution below were migrating upward [2]. This migration seemed to have not reached the top $1 \mathrm{~m}$ oxidation zone before the cell was flooded again after re-establishment of water flow. The re-installation of the wetland dissolved again the elements increasing their concentration at $2 \mathrm{~m}$. The mobilization of heavy metals downward is typical for humid raining climate so that it can be assumed that the 
implementation of the wetland is acting like a rainfall, dissolving and transporting the metals down to the water table [2]. These data showed that the water saturation is a key factor for oxidizing tailings wetland remediation and controls the kinetics of the remediation effectiveness together with the geochemical composition of the water used for remediation.

These concentrations started again to decrease three months after the incident, and this trend was maintained until the end of the experiment -780 days after the remediation started (Figure 6). The decrease of metal concentrations is probably due to adsorption on Fe oxides/hydroxides and co-precipitation, as well as to sulfide formation [34], as described before.

\section{Conclusions}

Two systems were studied in this temporal in situ bioremediation process, the Northern Cell at sea-level (NC) and the delta cell (DC) about $2 \mathrm{~m}$ above sea-level.

At the NC, the tailings consisted of sandy sediment due to grain size separation by the wave action, and the cell was close to the already remediated wetland-covered tailings. The water used for the remediation had $241 \mathrm{mg} / \mathrm{L}$ alkalinity and $8.36 \mathrm{~m} / \mathrm{L}$ DOC. After flooding, this water infiltrated rapidly, saturated the system (Figure 8A), consumed the acidity, oxidized the $\mathrm{Fe}(\mathrm{II})$ and hydrolyzed the subsequent $\mathrm{Fe}(\mathrm{III})$. As a consequence, iron was precipitating and co-precipitating with other metals, removing them from solution. The DOC contained in the flooding water provided additional carbon source for the heterotrophic bacteria, which degraded the organic matter and consumed the oxygen, leading to the creation of more reducing conditions. The upcoming of reducing conditions and the availability of sulfate promoted bacterial sulfate reduction and metal sulfide precipitation as well as alkalinity generation. Moreover, the organic matter binds some metals such as $\mathrm{Cu}$ and $\mathrm{Zn}$, removing them from water.

Figure 8. Characteristic of the remediation cells after the implementation of the wetland above the tailings.

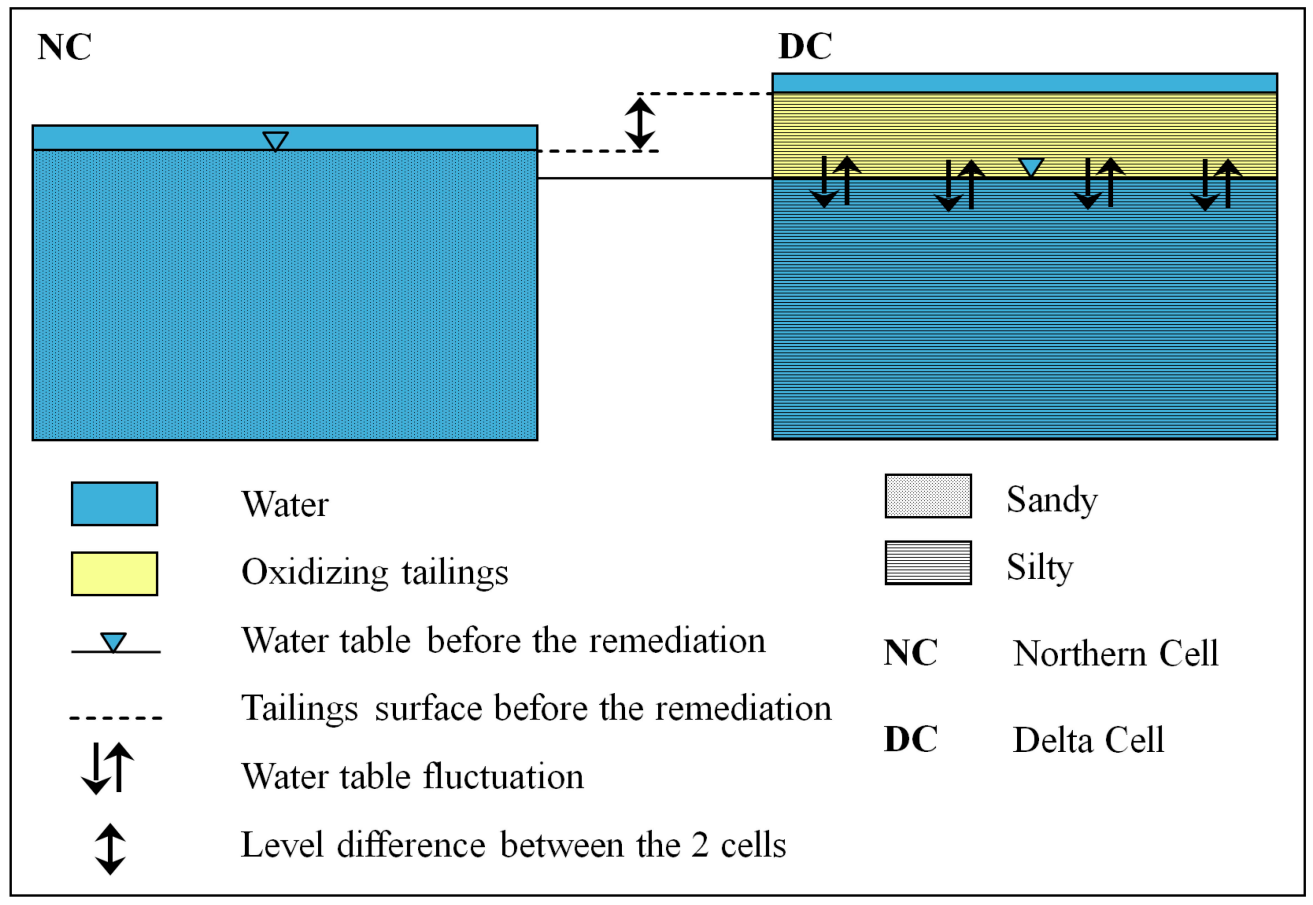


The arsenic coming with the inflowing water was adsorbed to the Fe(III) hydroxide. The water monitoring of this Northern Cell carried out during 15 months after the end of the experiment showed neutral $\mathrm{pH}$ and heavy metals below their detection limit, suggesting a good stability of the system.

In contrast, the delta cell was characterized by a mixed stratigraphy of silty, clayey, and very fine-sandy layers from 0 to $1 \mathrm{~m}$ depth. It is topographically situated 1 to $2 \mathrm{~m}$ higher than the northern cell and the old remediated tailings wetland due to additional tailings deposition at this area, following a break of a dike in 1992. The water used for the wetland implementation was neutral with $133 \mathrm{mg} / \mathrm{L}$ alkalinity, and $2.6 \mathrm{mg} / \mathrm{L}$ DOC. After flooding the water did not infiltrate rapidly due to grain size; the cell was not saturated during the entire course of the experiment. The cell had a water cover on the surface, followed by a vadose zone; and the groundwater table was fluctuating between 0.8 and $1.2 \mathrm{~m}$ (Figure 8B). However, slow infiltration of water was noted over time and observed during sampling. The same mechanisms of metal removal as described for the $\mathrm{NC}$ were also occurring in the DC, but they were slower and more progressive. The depletion of heavy metals in solution started after one year, and was much slower than in the northern remediation cell where the total metal removal took four months. The installation of reducing conditions also took a longer time, probably due to the non-saturation of the cell and to less DOC than in the NC.

Our data additionally has shown that changes in water supply (e.g., dry periods) and subsequent changes in the hydrogeological system might compromise the water saturation of the system and thus influence the efficiency of the approach. Therefore, to assure a sustainable remediation solution, the long-term water supply has to be ensured. Temporal changes might induce re-oxidation and/or seawater ingression, which might lead to liberation of contaminants into solution.

This study showed that the wetland implementation on oxidizing acidic tailings using alkalinity-rich and DOC-rich water is effective and rapid when the system is water saturated, i.e., water saturation is the key factor that triggers the geochemical condition necessary for the effective remediation. It showed also that the water chemistry is an important factor for the kinetics and effectiveness of the bioremediation. The $\mathrm{pH}$ and the redox are key parameters, which influence the dissolution and the sorption/precipitation mechanisms, and therefore the metal mobilization/immobilization processes.

\section{Acknowledgments}

We would like to thank Ezio Buselli and Rodolfo Vicetti, the directors of the Environmental Services of the Southern Peru Copper Corporation in Ilo, Peru, and their entire team from the laboratory for their excellent support and help during sampling and analysis. The study was financed by the Southern Peru Copper Corporation (SPCC) as part of the research agreement between the University of Lausanne and SPCC.

\section{Author Contributions}

Nouhou Diaby was in charge of sampling, field analysis, interpretations and scientific writing of this study under the supervision of Bernhard Dold. Final manuscript handling during the publication process was done by Bernhard Dold. 


\section{Conflicts of Interest}

The authors declare no conflict of interest.

\section{References}

1. Nordstrom, D.K.; Alpers, C.N. Geochemistry of Acid Mine Waste. In The Environmental Geochemistry of Ore Deposits. Part A: Processes, Techniques, and Health Issues; Plumlee, G.S., Logsdon, M.J., Eds.; Reviews in Economic Geology Volume 6A; Society of Economic Geologist: Littleton, CO, USA, 1999; pp. 133-160.

2. Dold, B.; Fontboté, L. Element cycling and secondary mineralogy in porphyry copper tailings as a function of climate, primary mineralogy, and mineral processing. J. Geochem. Explor. 2001, 74, $3-55$.

3. Johnson, D.B.; Hallberg, K.B. Acid mine drainage remediation options: A review. Sci. Total Environ. 2005, 338, 3-14.

4. Machemer, S.D.; Reynolds, J.S.; Laudon, L.S.; Wildeman, T.R. Balance of S in a constructed wetland built to treat acid mine drainage, Idaho Springs, Colorado, USA. Appl. Geochem. 1993, 8, 587-603.

5. Sheoran, A.S.; Bhandari, S. Treatment of mine water by a microbial mat: Bench-scale experiments. Mine Water Environ. 2005, 24, 38-42.

6. Catalan, L.J.J.; Yanful, E.K.; St-Arnaud, L. Field assessment of metal and sulfate fluxes during flooding of pre-oxidized mine tailings. Adv. Environ. Res. 2000, 4, 295-306.

7. Das, M.; Maiti, S.K. Comparison between availability of heavy metals in dry and wetland tailing of an abandoned copper tailing pond. Environ. Monit. Assess. 2008, 137, 343-350.

8. Moreno, L.; Neretnieks, I. Long-term environmental impact of tailings deposits. Hydrometallurgy 2006, 83, 176-183.

9. Widerlund, A.; Ebenå, G.; Landin, J. Potential biogeochemical and ecological development of a flooded tailings impoundment at the Kristineberg Zn-Cu mine, northern Sweden. Sci. Total Environ. 2004, 333, 249-266.

10. Dold, B.; Diaby, N.; Spangenberg, J.E. Remediation of a marine shore tailings deposit and the importance of water-rock interaction on element cycling in the coastal aquifer. Environ. Sci. Technol. 2011, 45, 4876-4883.

11. Elliott, P.; Ragusa, S.; Catcheside, D. Growth of sulfate-reducing bacteria under acidic conditions in an upflow anaerobic bioreactor as a treatment system for acid mine drainage. Water Res. 1998, $32,3724-3730$.

12. Fortin, D.; Roy, M.; Rioux, J.P.; Thibault, P.J. Occurrence of sulfate-reducing bacteria under a wide range of physico-chemical conditions in $\mathrm{Au}$ and $\mathrm{Cu}-\mathrm{Zn}$ mine tailings. FEMS Microbiol. Ecol. 2000, 33, 197-208.

13. Luptakova, A.; Kusnierova, M. Bioremediation of acid mine drainage contaminated by SRB. Hydrometallurgy 2005, 77, 97-102.

14. Praharaj, T.; Fortin, D. Indicators of microbial sulfate reduction in acidic sulfide-rich mine tailings. Geomicrobiol. J. 2004, 21, 457-467. 
15. Canmet and Coastech Research Inc. Acid Rock Prediction Manual; Canada Centre for Mineral and Energy Technology: Ottawa, ON, Canada, 1991.

16. Coggans, C.J.; Blowes, D.W.; Robertson, W.D.; Jambor, J.L. The Hydrogeochemistry of a Nickel-Mine Tailings Impoundment-Copper Cliff, Ontario. In The Environmental Geochemistry of Ore Deposits. Part A: Processes, Techniques, and Health Issues; Plumlee, G.S., Logsdon, M.J., Eds.; Reviews in Economic Geology Volume 6A; Society of Economic Geologist: Littleton, CO, USA, 1999; pp. 447-478.

17. Dold, B. Speciation of the most soluble phases in a sequential extraction procedure adapted for geochemical studies of copper sulfide mine waste. J. Geochem. Explor. 2003, 80, 55-68.

18. Dold, B. Element flows associated with marine shore mine tailings deposits. Environ. Sci. Technol. 2006, 40, 752-758.

19. Hammarstrom, J.M.; Seal, R.R., II; Meier, A.L.; Kornfeld, J.M. Secondary sulfate minerals associated with acid drainage in the eastern US: Recycling of metals and acidity in surficial environments. Chem. Geol. 2005, 215, 407-431.

20. Smuda, J.; Dold, B.; Friese, K.; Morgenstern, P.; Glaesser, W. Mineralogical and geochemical study of element mobility at the sulfide-rich Excelsior waste rock dump from the polymetallic Zn-Pb-(Ag-Bi-Cu) deposit, Cerro de Pasco, Peru. J. Geochem. Explor. 2007, 92, 97-110.

21. Nealson, K.H.; Saffarini, D. Iron and Manganese in Anaerobic Respiration: Environmental Significance, Physiology, and Regulation. Annu. Rev. Microbiol. 1994, 48, 311-343.

22. Parkhurst, D.L.; Appelo, C.A.J. User's Guide to PHREEQC (Version 2)—A Computer Program for Speciation, Batchreaction, One-Dimensional Transport, and Inverse Geochemical Calculations; Water-Resources Investigations Report 99-4259; U.S. Geological Survey: Reston, VA, USA, 1999.

23. Woulds, C.; Ngwenya, B.T. Geochemical processes governing the performance of a constructed wetland treating acid mine drainage, Central Scotland. Appl. Geochem. 2004, 19, 1773-1783.

24. Webster, J.G.; Swedlund, P.J.; Webster, K.S. Trace metal adsorption onto an acid mine drainage iron(III)oxyhydry sulfate. Environ. Sci. Technol. 1998, 32, 1362-1368.

25. Carlsson, E.; Öhlander, B.; Holmström, H. Geochemistry of the infiltrating water in the vadose zone of a remediated tailings impoundment, Kristineberg mine, northern Sweden. Appl. Geochem. 2003, 18, 659-674.

26. Holmstrom, H.; Salmon, U.J.; Carlsson, E.; Petrov, P.; Ohlander, B. Geochemical investigations of sulfide-bearing tailings at Kristineberg, northern Sweden, a few years after remediation. Sci. Total Environ. 2001, 273, 111-133.

27. Peltier, E.F.; Webb, S.M.; Gaillard, J.F. Zinc and lead sequestration in an impacted wetland system. Adv. Environ. Res. 2003, 8, 103-112.

28. Wilkie, J.A.; Hering, J.G. Adsorption of arsenic onto hydrous ferric oxide: Effects of adsorbate/adsorbent ratios and co-occurring solutes. Colloids Surf. A Physicochem. Eng. Asp. 1996, 107, 97-110.

29. Fox, P.M.; Doner, H.E. Accumulation, release, and solubility of arsenic, molybdenum, and vanadium in wetland sediments. J. Environ. Qual. 2003, 32, 2428-2435.

30. Bone, S.E.; Eagle, M.; Charette, M.A. Geochemical cycling of arsenic in a coastal aquifer. Environ. Sci. Technol. 2006, 40, 3273-3278. 
31. Miyata, N.; Tani, Y.; Sakata, M.; Iwahori, K. Microbial manganese oxide formation and interaction with toxic metal ions. J. Biosci. Bioeng. 2007, 104, 1-8.

32. O’Day, P.A.; Vlassopoulos, D.; Root, R.; Rivera, N. The influence of sulfur and iron on dissolved arsenic concentrations in the shallow subsurface under changing redox conditions. Proc. Natl. Acad. Sci. USA 2004, 101, 13703-13708.

33. Goldberg, S.; Forster, H.S.; Godfrey, C.L. Molybdenum adsorption on oxides, clay minerals, and soils. Soil Sci. Soc. Am. J. 1996, 60, 425-432.

34. O’Sullivan, A.D.; Moran, B.M.; Otte, M.L. Accumulation and fate of contaminants ( $\mathrm{Zn}, \mathrm{Pb}, \mathrm{Fe}$ and $\mathrm{S}$ ) in substrates of wetlands constructed for treating mine wastewater. Water Air Soil Pollut. 2004, 157, 345-364.

(C) 2014 by the authors; licensee MDPI, Basel, Switzerland. This article is an open access article distributed under the terms and conditions of the Creative Commons Attribution license (http://creativecommons.org/licenses/by/3.0/). 